\title{
WHY SO MANY LOCAL ENTREPRENEURS?
}

\author{
Claudio Michelacci and Olmo Silva
}

CEMFI Working Paper No. 0506

May 2005

CEMFI

Casado del Alisal 5; 28014 Madrid

Tel. (34) 914290 551. Fax (34) 914291056

Internet: www.cemfi.es

We thank Luigi Guiso for help with the data and Francesco Daveri, Andrea Ichino, Esteban Jaimovich, Omar Licandro, Steve Machin, Barbara Petrongolo, Guido Schwerdt, and seminar participants at EUI, LSE and UCL for useful comments. 
CEMFI Working Paper 0506

May 2005

\title{
WHY SO MANY LOCAL ENTREPRENEURS?
}

\begin{abstract}
We document that the fraction of entrepreneurs who work in the region where they were born is significantly higher than the corresponding fraction for dependent workers. This difference is more pronounced in more developed regions and positively related to the degree of local financial development. Firms created by locals are more valuable and bigger (in terms of capital and employment), operate with more capital intensive technologies, and are able to obtain greater financing per unit of capital invested, than firms created by non-locals. This evidence suggests that there are so many local entrepreneurs because locals can better exploit the financial opportunities available in the region where they were born. This can help explaining how local financial development cause persistent disparities in entrepreneurial activity, technology, and income.
\end{abstract}

JEL Codes: J23, O12, O16, Z13.

Keywords: Entrepreneurship, economic and financial development, social capital.

Claudio Michelacci

CEMFI

c.michelacci@cemfi.es
Olmo Silva

CEP and EUI

o.silva@Ise.ac.uk 


\section{Introduction}

It is well known that cross-country disparities in income per capita are very persistent and that differences in technology explain a major part of the cross-country variation, see Lucas (1990) and Hall and Jones (1999). But why do differences in technology persist? From a Schumpeterian perspective, entrepreneurs are the main determinant of one country's technological performance: they innovate and adopt new modes of production, thereby spurring technological progress and productivity growth. ${ }^{1}$ Following Schumpeter (1911), a vast literature has documented a positive link between entrepreneurial activity and one country's ability to achieve prosperity; for a review see Acs and Audretsch (2003). Under this perspective, lack of entrepreneurship is a likely culprit of the lack of technological convergence.

In this paper, we provide evidence that new businesses in a given location are mainly created by local entrepreneurs. The tendency is more pronounced in more developed regions. Overall this suggests that entrepreneurship can hardly be regarded as a mobile factor of production that gets allocated to arbitrage away technology differences. Given that business creation is a primary source of technological adoption and innovation, this also suggests that the nurturing of local entrepreneurship is key to foster technological catching up.

To document that local entrepreneurship accounts for an important part of business creation, we focus on Italy, a country which has been unified, from both a political and a regulatory point of view, for the last 140 years. This allows us to control for possible differences in the judicial and legal system or for other country specific characteristics, that could drive the results. Italy also exhibits remarkable regional differences in technology and GDP per capita, which makes it particularly suitable for our investigation. The data come from the Survey of Household Income and Wealth (SHIW) collected by the

\footnotetext{
${ }^{1}$ Michelacci (2003) and Acs et al. (2004) formally analyze the role of entrepreneurship in endogenous growth models. They argue that entrepreneurship is the key factor that allows scientific knowledge to affect technology.
} 
Bank of Italy and have been recently extensively analyzed, see Guiso et al. (2004a, 2004b). Exploiting several dimensions of the data set, we document the following empirical regularities:

1. The fraction of entrepreneurs who start up their business in the region where they were born is significantly higher than the corresponding fraction for dependent workers. We refer to this difference as to a local bias in entrepreneurship (LBE).

2. LBE is more pronounced for larger businesses (in terms of market value and number of employees).

3. LBE is positively related to the level of economic development of the region, as measured by GDP per capita and the unemployment rate. Yet, it is almost unrelated to the degree of specialization of entrepreneurial activities and their density.

4. Firms created by locals are bigger (in terms of market value, number of employees and capital), operate with more capital intensive technologies, and receive greater financing per unit of capital invested, than firms created by non-locals.

5. LBE is increasing in the degree of local financial development, as measured by Guiso et al. (2004a).

As documented by, among others, Blanchflower and Oswald (1998), Evans and Jovanovic (1989) and Holtz-Eakin et al. (1994), funds provision is an important concern when creating a new business. Thus, we interpret the previous findings as suggesting that LBE results from the combination of two factors, independently put forth in the literature. First, distance matters in the provision of fund, so that firms have to locate close to their financiers to obtain financing. Petersen and Rajan (2002) provide direct evidence about the importance of distance in the provision of funds to firms. A theoretical analysis is provided by Williamson (1987). Second, locals may have some sort of "regional specific collateral" that facilitates the access to credit and that would be lost if they had to move 
and set-up their business in a different location. For example, local financiers, such as banks and venture capitalists, may have privileged information about individuals who have been living in a given location for several years, or it could be that the moral hazard problem associated with borrowing is less severe due to peer effects or local social pressure for individuals who reside in the same region where they were born (see Arnott and Stiglitz (1991)). This would explain both why local financial development benefits proportionally more locals than foreigners (Fact 5) and why local start-ups are bigger, more leveraged and operate with more capital intensive technologies (Fact 4). Since business creation is a primary source of technological adoption and innovation, this mechanism can help explaining how differences in local financial development cause persistent disparities in income and technology across regions and countries. Guiso et al. (2004a) provide direct evidence that local financial development spurs economic development.

There are other possible explanations for LBE. These however seem to contradict some of the previous findings. For example, LBE could arise if individuals choose to become entrepreneurs in the native location because they strongly prefer to reside there, but lack of employment opportunities as dependent workers. Alba-Ramirez (1994), MartinezGranado (2002) and Chelli and Rosti (1998) document how this may explain some entrepreneurial spells in Spain, U.K. and Italy, respectively. If this was the main explanation for LBE, however, we would expect a negative correlation between LBE and the local level of development: in particular LBE should be inversely related to the unemployment rate in the region of residence, which does not appear to be the case (Fact 3). This possible explanation also seems at odd with the finding that locals create more valuable businesses than non-locals (Fact 4).

Alternatively, the combination of entrepreneurial learning and regional sectoral specialization may provide an explanation for LBE. Consider a situation where regions tend to have a natural advantage in some sectors of activity, and that entrepreneurs tend to start-up their business in the region where the associated sector has the greatest natural 
advantage. Also assume that, due to learning and technological spill-overs, local individuals have a greater probability than non-locals of acquiring entrepreneurial ideas specific to the sector where the region has its natural advantage. This mechanism would also induce LBE. Guiso and Schivardi (2003) provide some evidence supporting the relevance of this mechanism. Our findings suggest however that entrepreneurial learning can hardly account for the previous findings. In particular this explanation would tend to predict that LBE is greater in regions where the sectoral natural advantage and the scope for learning from other entrepreneurs are greater. Fact 3 documents that LBE is only mildly related to the degree of sectoral specialization of entrepreneurial activities and to the number of entrepreneurs present in the regions of birth. This seems to limit the scope for an explanation based on the combination of entrepreneurial learning and regional sectoral specialization.

The paper is organized as follows. Section 2 contains a simple formalization of why LBE can arise. Section 3 describes the data. Section 4 documents LBE. Section 5 discusses the role of local credit markets. Section 6 concludes.

\section{Possible explanations for LBE}

We next sketch a simple model to highlight why the fraction of entrepreneurs who set up their business in the location where they were born may be higher than the corresponding fraction for dependent workers - i.e. to highlight why a local bias in entrepreneurship (LBE) may arise. We show how the three different mechanisms discussed in the introduction (a preferential access of locals to local markets, lack of employment opportunities, and entrepreneurial learning) can generate LBE. The model borrows from Lucas (1978) and it is simply intended to help guiding the empirical analysis that follows.

Consider an economy characterized by two perfectly symmetric locations $a$ and $b$. In each location there are two sectors $A$ and $B$. Location $a$ and $b$ have a natural advantage in sector $A$ and $B$, respectively. 
There is a measure one of individuals born in each location. An individual receives some utility $\tilde{u}$ from living in the location where she is born. A fraction $\alpha$ of individuals is attached to the native location and has $\tilde{u}=u$, while the remaining fraction is unattached and has $\tilde{u}=0$. With probability $\rho$ an individual specializes in the sector where the location has its natural advantage. Otherwise the individual specializes in the other sector. An individual specialized in a sector can operate just in that sector, i.e. she has no abilities and skills to work (as either worker or entrepreneur) in the other sector.

Some individuals may obtain an entrepreneurial idea of value $\nu$, which is sector specific. The value of $\nu$ is a drawing from a uniform distribution with support on the unit interval, $\nu \sim U[0,1]$. An individual who is specialized in the sector where her native location has a natural advantage obtains an idea with probability $\gamma$. The corresponding probability for an individual who is specialized in the other sector is $\beta$. The possible difference between $\gamma$ and $\beta$ reflects the existence of social learning and technological spill-overs on the possibility of becoming entrepreneur, which may differ for locals and non-locals.

An idea of value $\nu$ yields a business of value $\tilde{Z}$ equal to $Z+\nu$, if the business is created in the location with a natural advantage in the given sector, while $\tilde{Z}$ equals $\nu$ if the business is created in the other location. The parameter $Z \geq 0$ reflects the strength of natural advantage. Running a firm in the location where the individual is born has a cost normalized to zero while non-locals incur a cost $c_{f} \geq 0$. This may capture the fact that locals have a preferential access to local markets, say due to a greater endowment of social capital and to stronger local connections. The difference between $\tilde{Z}$ and the cost of running the firm determines firm's profits.

Working in the sector where the location has its natural advantage pays a wage $\bar{w}$, while the wage paid in the other sector is $\underline{w}<\bar{w}$. These compensations have to be interpreted as reflecting expected wage income. Thus, they incorporate the employment probability in the sector and the associated unemployment risk. ${ }^{2}$

\footnotetext{
${ }^{2}$ For simplicity we maintain wages and part of firm's profits as exogenous, although they could be easily endogenized by assuming that firms demand labour to produce and that the labour market in each
} 
For simplicity all probabilities $\alpha, \rho, \gamma$ and $\beta$ are taken to be strictly between zero and one. To guarantee that in each location there are both local and non-locals workers and entrepreneurs, we make the following simplifying assumptions:

$$
\begin{aligned}
u & >\max \left(Z-c_{f}, \bar{w}-\underline{w}\right), \\
Z & >c_{f}, \\
1 & \geq \max \left(\underline{w}, \bar{w}-Z+c_{f}\right) .
\end{aligned}
$$

Condition (1) implies that attached individuals never move, so that there always exist some individuals that choose to work in the sector where the location fails to have its natural advantage. Conditions (2) and (3) guarantee that some entrepreneurs are nonlocals and that in each sector there are some entrepreneurs. ${ }^{3}$

To sum-up, individuals are identified by whether they are attached to their native location, whether their sector of specialization coincides with the sector where their native location has its natural advantage and whether they have an entrepreneurial idea and if so by its value. The timing is as follows: an individual first observes her sector of specialization, then her possibilities in the labour market and whether she has an entrepreneurial idea and (possibly) its value. At that point she chooses whether to become a worker or an entrepreneur, and where to reside.

As a result, attached individuals never move. Similarly, an individual who is specialized in the sector where her native location has a natural advantage remains living in the native location. She becomes entrepreneur if she obtains an entrepreneurial idea of value $\nu \geq \bar{w}-Z$. Otherwise she becomes a worker. Individuals who are specialized in the sector where the native location fails to have a natural advantage always move to the other location, if unattached, while they remain in the native location, if attached. If unattached, they become entrepreneurs only if they obtain an entrepreneurial idea of sector and location clears.

${ }^{3}$ Notice that, under some Inada type assumptions, all these conditions would naturally be satisfied in the equilibrium of the model where firms demand labour to produce and wages are determined so as to clear the labour market. 
value $\nu>\bar{w}-Z+c_{f}$. If attached, they become entrepreneurs only if $\nu>\underline{w}$.

One can then proceed to calculate, in each location, the total number of workers employed, $N_{w}$, the total number of entrepreneurs, $N_{e}$ and then partition each of these quantities into the number of locals and non-locals (computations are reported in the Appendix). This allows to express the difference between the fraction of local entrepreneurs over the total number of entrepreneurs, $s_{e}$, and the fraction of local workers over the total number of workers, $s_{w}$, as equal to:

$$
\begin{aligned}
\mathrm{LBE} \equiv & s_{e}-s_{w}=\frac{(1-\alpha)(1-\rho)}{N_{e} N_{w}} \\
& \cdot\left\{[\alpha(1-\rho)+\rho \beta] c_{f}+\alpha(1-\rho)(\bar{w}-Z-\underline{w})+\rho(1-\bar{w}+Z)(\gamma-\beta)\right\} .
\end{aligned}
$$

The second line of the expression implies that:

Proposition 1 There exists a local bias in entrepreneurship (LBE is positive) if at least one of the following holds true: either (i) locals generally have an advantage at innovating in their native location, i.e. $c_{f}>0$, or (ii) some attached individuals have sufficiently bad employment opportunities as dependent worker, i.e. $\underline{w}<\bar{w}-Z$, or (iii) locals have a greater probability than non-locals of obtaining an entrepreneurial idea in the sector where the native location has a natural advantage, i.e. $\gamma>\beta$.

The Proposition shows how different mechanisms could generate LBE. Condition $(i)$ shows how a preferential access of locals to local markets may cause LBE. Condition (ii) implies that LBE could be the result of lack of employment opportunities as dependent worker. If some people do not want to abandon the native location and lack job opportunities as dependent workers, they may decide to create their own business, thereby inducing LBE. Finally condition (iii) says that LBE may be due to the fact that locals benefit from particularly strong technological spill-overs in the sector where the native location has a natural advantage. This simple model will help us in framing the analysis that follows. 


\section{Data}

We start describing the data and then discuss how well they represent the population of Italian firms.

\subsection{Description}

We use information contained in the Survey of Household Income and Wealth (SHIW) collected by the Bank of Italy. SHIW provides a representative picture of Italian households, both in terms of income dynamics and occupational choices. We focus on the 1991, 1993 and 1995 waves of the survey, because they contain detailed information on individual decisions about occupational choice and geographical mobility. We only sample working individuals aged between 18 and 65, who are heads of household. Heads of household are the most relevant decisional unit within a household and they are most likely to actively engage in the labour market. This reduces sample selection problems related to labor market participation. ${ }^{4}$ Further details about the construction of the data set and the definition of the variables used in the analysis are contained in the Appendix.

We start constructing the variable Local as a dummy variable taking the value of one if the individual works in the Province where she was born. ${ }^{5}$ Italy is currently divided in 20 Regions and 103 Provinces. An Italian province roughly corresponds to a US county. Individuals sampled in SHIW are also asked to report about their main working activity. First, they have to state whether they work as dependent or non-dependent workers. If dependent worker, they then report whether they work as blue or white collar. If non-dependent worker, they report whether they are 1) entrepreneurs, 2) self-employed/craftsmen, 3) professionals, 4) manager/partners of societies and 5) workers of family firms. On the basis

\footnotetext{
${ }^{4}$ We also drop individuals born in the Aosta Province. In fact, no people living in that Province were interviewed in any of SHIW waves implying that no information about geographical mobility is available.

${ }^{5} \mathrm{We}$ assume that individuals work and live in the same Province as no information about working location is available. To check for the validity of this assumption, we also ran all the analysis using Regions rather than Provinces to identify geographic mobility. As Regions cover large portions of the Italian territory, it is unlikely that individuals live and work in different Regions. Results remain broadly unchanged, which makes us confident about the plausibility of the assumption.
} 
of this information we construct the variable Worker as a dummy variable identifying individuals who work as dependent workers (either blue or white collar) and the variable Entrepreneur as a dummy variable identifying non-dependent workers who work as either 1) entrepreneurs, 2) self-employed/craftsmen, 3) professionals or 4) managers/partners of societies. Notice that, according to SHIW explanatory notes, the main difference between entrepreneurs tout court and self-employed/craftsmen relates to the number of people employed in the activity, with the latter mainly working alone. Manager/partners of societies are defined as individuals owning shares of the firm and actively working and managing the business. We therefore classify them as Entrepreneurs, since risk bearing and decision making are distinctive features of entrepreneurship. By the same logic we also include professionals in the definition of Entrepreneur. ${ }^{6}$ Conversely, we exclude workers of family firms, because in many cases jobs in family businesses require little leadership and innovative activities. ${ }^{7}$

We also construct the variable Start-up as a dummy variable identifying individuals who start up a new business. We consider two alternative definitions of start-ups. In the first, we identify as start-ups all Entrepreneurs who declare to "have found their job by setting-up their activity" (Start-up1). In the second, we classify as start-ups all Entrepreneurs who "did not find their job by taking up parents' activities" (Start-up2). Based on the first definition, more than $60 \%$ of all Entrepreneurs classified as non-startups actually took up relatives' businesses, which suggests that Start-up2 better identifies true start-ups. Questions about the channel whereby a job was found were not asked in 1995. To increase the degrees of freedom, in some of the specifications below we also add data for the 1995. In that case we identify as start-ups those Entrepreneurs who are not working in the same occupation and sector as the one of their parents. This is

\footnotetext{
${ }^{6}$ This however may be more controversial, since business creation is not always clearly associated with becoming a professional. We checked that excluding professionals from the definition of Entrepreneur does not affect the results below. In order to avoid cluttering the tables we do not report the results.

${ }^{7}$ According to Italian laws, both owners and workers of family firms are classified as non-dependent workers and paid on the basis of their contribution to the economic activity of the family venture.
} 
quite restrictive in distinguishing start-ups from other entrepreneurs, since in principle start-ups could be created in the same sector and occupation as that of their parents.

We also use information about individuals' Age, Educational achievement, Marital status and Number of children. Descriptive statistics for the variables retained in the analysis are reported in Table 1. Importantly, we also derive from SHIW information about the monetary value of the entrepreneurial venture, as well as other measures of firm's size. Entrepreneurs in SHIW are asked to estimate the market value of their participation in the venture, in case of selling it. This is the basis to calculate the Firm's Market Value. We also consider indicators for the Employment Size of the firm, the Capital Stock and the Capital-Labor ratio. To measure the capital stock of the firm we use information about capital depreciation, which corresponds to the variable "Ammortamenti" in the survey. "Ammortamenti" is the amount of capital that has to be imputed by law to the current year of production. This legal requirement is set taking into account the sector of activity, the age and the legal structure of the business venture and it represents a proxy for the capital stock of the firm. To have a proxy for the capital-labor ratio, we divide the value of "Ammortamenti" by the number of people working at the firm.

All the variables characterizing the size of the firm (in terms of value, employment or capital) are self-reported and thus likely to be subject to measurement error. The Employment Size of the firm is less likely to be subject to under-reporting than the Firm's Value, which tends to be understated for fear that statistical information may be leaked to the tax authority, see OECD (1992) and (2000) for evidence about this.

\subsection{Is our sample representative?}

Since SHIW was not designed to be representative of firms' population (but of Italian Households), we start assessing whether, and how well, the characteristics of the ventures sampled in SHIW track features of the population of Italian firms.

To do this, we compare some statistics derived from our sample with similar records obtained from ISTAT 1991 Census of Italian Firms and Services. We study firms' char- 
acteristics along the size and geographical location dimensions since they are key for the analysis that follows. We also discuss some evidence about the sectoral distribution of firms sampled in SHIW, which is also relevant for some of the exercises pursued below. It is worth mentioning that ISTAT Census only marginally covers agricultural activities. This may partly alter the comparability of the two samples. For this reason, we report figures both including and excluding agricultural activities from SHIW computations.

Table 2 compares the size distribution of firms in the two datasets. ISTAT data shows that Italian firms tend to be quite small. SHIW reproduces this feature remarkably well and irrespectively of the exclusion of the agricultural sector from the analysis. ${ }^{8}$ Table 3 reveals that the geographical distribution of the firms in SHIW tracks closely that obtained by using Census data. ${ }^{9}$ The only remarkable exception is Lombardia, one of the most heavily industrialized Regions in Italy: although Lombardia ranks on the top in both datasets, its absolute relevance is more striking in the ISTAT data than in SHIW. This is probably due to the fact that Lombardia is a Region where many foreign and multinational firms are located. Since SHIW only sample Italian individuals, foreign owned businesses are not in our dataset. While this may explain the observed discrepancy, it might also bias our analysis since it may lead us to underestimate the geographical mobility of entrepreneurs by omitting an important component of the entrepreneurial pool. As long as the difference between ISTAT and SHIW firms' geographical distribution capture the incidence of foreign and multinational firms, this measure can be used to assess the robustness of our findings. In the analysis that follows, we check that our results are not driven by omitting foreign and multinational firms from our sample. When we compare the sectoral distribution of firms in SHIW with that in ISTAT Census, we find that SHIW slightly under-represents Trade and Commerce, while it over-represents

\footnotetext{
${ }^{8}$ For comparison purposes, notice that $75 \%$ of US firms had between 1 and 9 employees, $12 \%$ between 10 and 19 and $13 \%$ at least 20. See US Census Bureau Data, 2001 at: https://www.sba.gov/advo/stats/data.html

${ }^{9}$ We also assessed the geographical distribution of firms by Province. The results are in line with those obtained using Regions. They are not reported to save space.
} 
Manufacturing. Overall the two surveys provide a very similar picture of the sectoral composition of Italian firms.

\section{Evidence of LBE}

We start documenting the existence of LBE. We then show how LBE relates to i) the size of the firm, ii) the development of the region and iii) the sectoral specialization of entrepreneurial activities.

\subsection{Basic evidence}

To measure the magnitude and significance of LBE we run the following regression:

$$
\operatorname{Local}_{i}=\omega+\lambda \operatorname{En}_{i}+\delta X_{i}+\varepsilon_{i}
$$

where, as previously discussed, Local $_{i}$ is a dummy variable taking value one if individual $i$ works in the province where she was born while $E n_{i}$ is a dummy variable taking value one for individuals who are either Entrepreneurs or Start-ups, depending on the specification. Whenever $E n_{i}$ identifies start-ups entrepreneurs we include in the vector of controls a dummy for non-start up entrepreneurs. As a result, the intercept $\omega$ always identifies the fraction of dependent workers (Workers) who work in the province where they were born. The $\lambda$ coefficient instead measures LBE for either Entrepreneurs or Start-ups. The vector $X_{i}$ include a set of individual and aggregate control variables, that vary depending on the specification. Our approach is thus descriptive: it allows to quantify the difference between the fraction of local entrepreneurs and local dependent workers, after controlling for some relevant characteristics.

We start by considering the sample concerning 1991 and 1993. Table 4 reports the fraction of local dependent workers (i.e. the constant $\omega$ ) and the local bias in entrepreneurship, using different definitions and specifications. Columns 1 and 2 quantifies LBE when comparing Workers to Entrepreneurs, with and without controlling for the following 
set of characteristics: age, gender, four dummies for educational achievement, marital status and number of children; five macro region dummies (North-West, North-East, Center, South and Islands); and a full set of year dummies. ${ }^{10}$ This set of regressors is included to assure that some basic individual and aggregate attributes do not drive our findings. Columns 3 to 6 quantify LBE when considering Start-ups rather than Entrepreneurs, using either definition one or two. Finally, Columns 7 and 8 break down the share of local dependent workers into white and blue collars, and quantifies LBE for Start-ups.

The size of LBE is around 7 percentage points. This is the results of the difference between a share of local Entrepreneurs which is around $79 \%$ and a share of local dependent workers, which is around $72 \%$. These numbers are quite high, which suggests that LBE cannot be disregarded on the basis of its little economic relevance. LBE remains almost unchanged after controlling for individual characteristics and it does not vary substantially depending on whether we focus on Entrepreneurs or Start-ups. This implies that the transmission of entrepreneurial activities from one generation to the next it is unlikely to explain LBE. ${ }^{11}$ When the fraction of dependent workers is split into white and blue collars (Columns 7 and 8), we find that LBE is about 7.5 percentage points with respect to blue collars, and 4.5 percentage points (but still highly significant) relative to white collars.

The previous findings remains broadly unchanged when adding the third SHIW wave (Table 5). Columns 1 and 3 reveal that LBE is of the order of 6.5 to 7.5 percentage points when no controls are used. After adding the controls (Columns 2 and 4), we still find that LBE is positive, statistically significant and of a similar order of magnitude. Given that the inclusion of the 1995 wave leaves the results unchanged, in the remaining of the analysis we make use of all the three SHIW waves, to increase degrees of freedom.

\footnotetext{
${ }^{10}$ As a robustness check, we also augmented our regressions with industry dummies; our results were fully confirmed.

${ }^{11}$ Also notice that we excluded family firms from the our definition of Entrepreneur, which further reduces the problem of intergenerational transmission of entrepreneurial activities.
} 
Moreover, we present only results pertaining to start-ups entrepreneurs. ${ }^{12}$ Indeed startups provide the most direct evidence about local business creation, which is the focus of the paper. ${ }^{13}$

We discussed above how the exclusions of foreign owned businesses from our dataset may affect our results. To assess the robustness of our findings to this concern, we measure the incidence of foreign and multinational firms in the region by calculating the difference between ISTAT and SHIW firms' geographical distribution. We then evaluate how the introduction of this control in the regression affects LBE and, how it interacts with LBE. Columns 6 of Table 5 reports on this exercise. Once the ISTAT-SHIW discrepancy in the geographical distribution of business ventures and its interaction with the entrepreneurial status are included as additional regressors, we find that LBE is as sizable and significant as before. The interaction term is positive but just marginally significant. Overall this reinforces the conviction that the omission of multinational and foreign owned businesses from the sample does not drive our results.

\subsection{LBE and firm's size}

We also characterize LBE relative to the size of the firm. Panel A of Table 6 deals with employment size. The first two Columns quantify LBE for firms employing one or more than one worker; in the last two Columns, we repeat the exercise for firms employing five or more than five workers, which corresponds to the top decile of the distribution of employment size of firms in SHIW. We find that the share of local entrepreneurs is always significantly higher than the share of local dependent workers. Interestingly LBE is increasing in the number of people employed at the firm: it ranges between 10 and 11

\footnotetext{
${ }^{12}$ We also report only the results with the second definition of start-ups. The magnitude of LBE gets even amplified when considering the first definition. This is coherent with our previous considerations that the first definition may not be restrictive enough in distinguishing start-ups from other entrepreneurs.

${ }^{13}$ In any case, we checked that our findinds remain valid when using all entrepreneurs rather than just start-ups. The results are available from the authors upon request.
} 
percentage points when considering larger businesses. ${ }^{14}$

We also rank entrepreneurs according to the market value of their business, see Panel B of Table 6. In the first two Columns, the median value of the profitability distribution is used to split the sample (the median value being 30 millions of 1991 Italian liras). In the last two Columns, instead, entrepreneurs in the top decile of the value distribution are contrasted with other entrepreneurs and with dependent workers (the top decile being 300 millions of 1991 Italian liras). Irrespectively of the value of the firm considered, the share of local entrepreneurs is always higher than the corresponding share of dependent workers. Interestingly, LBE is increasing in the value of the firm: for start-ups in the top decile of the distribution of firm's values, LBE is as high as 10 percentage points.

The findings presented in Table 6 highlight a positive relation between measures of firm's size and LBE. To corroborate the claim, we also compare the average size of local and non-local firms. To do so, we consider (i) the employment size of the firm; (ii) the capital stock, as proxied by yearly "Ammortamenti" (capital depreciation) and (iii) the capital-labor ratio. For the sake of comparison, we also compare the average wage of local and non-local dependent workers.

Table 7 reports the results obtained by regressing the proxies for the firm size and capital intensity on a dummy identifying local entrepreneurs; Columns 2, 4 and 6 also include the following controls: individuals' gender, age, family status, number of children, job tenure and average hours worked per week; indicators for the size of the city or town where the individual lives; dummy variables for educational achievement, less than full year activities, sector of occupation and calendar year; and five macro region dummies. We find that firms managed by local entrepreneurs are larger in size and more capital intense. Given the average size of firms, the employment advantage of local start-ups is as high as $37 \%$. Similarly, local firms have on average $40 \%$ more capital and $38 \%$ higher

\footnotetext{
${ }^{14}$ We also studied whether the fraction of local dependent workers varies in firms of different size. We did not find any significant pattern.
} 
capital-labor ratios than non-local firms. ${ }^{15}$

We repeat a similar exercise for dependent workers, considering both their total wage bills and their net wages. We control for all the variables included in the previous regression plus the local unemployment rate. The results are reported in Table 8. A remarkably different picture emerges: local dependent workers earn significantly lower total wage bills and net wages, than migrants do, which is in line with the findings in the immigration literature; see for example Borjas (1987) and Borjas et al. (1992). The wage premium of immigrants is to be imputed to non-local white collars immigrants who earn significantly more than local white workers do. Given the average total wage bill, local white collars earn $5 \%$ less than movers. A similar figure emerges when comparing net wages.

Thus there exist remarkable differences between dependent workers and entrepreneurs in that dependent workers who migrate gain higher wages, while non-local entrepreneurs create smaller and less valuable businesses than locals.

\subsection{LBE and local economic development}

So far, we have ranked dependent workers and entrepreneurs by using individual and business characteristics. We next discuss how LBE is related to some measures of local economic development. We first document the relation between LBE and local unemployment rates and then how it is related to GDP per capita.

In Table 9 we first analyze the relation between local unemployment rates and LBE by interacting the entrepreneurial status variable with the local unemployment rate; this is done in Columns 1 and 2. Unemployment rates by Regions of residence were obtained from ISTAT Labor Force Surveys for 1991, 1993 and 1995, and averaged over the three years. ${ }^{16}$ Since we are interested in analyzing how labour market conditions affect LBE,

\footnotetext{
${ }^{15}$ We also repeated the same exercise using the pecuniary value of the firm. As already mentioned, this measure is strongly subject to under-reporting, especially at the top of the distribution. Also in this case, we find that local start-ups have higher pecuniary value than non-local ones although the difference is somewhat less significant than that obtained with employment size and capital.

${ }^{16}$ Unemployment rates defined over Provinces could not be computed as provincial codes in ISTATLabor Force Surveys are protected for confidentiality reasons.
} 
we would like to use the unemployment rate at the date when the business was created or the worker become employed. These are however difficult to be imputed. Nevertheless, unemployment differentials across Italian Regions have not (drastically) changed over the past decade. Moreover, current average unemployment rates may provide a better approximation to the life-time employment opportunities which affect individuals' working choices. While Columns 1 presents raw figures, Columns 2 includes the usual set of individual and aggregate controls.

We find a negative relation between LBE and local unemployment rates. Indeed the interaction term between the entrepreneurial status variable and the unemployment rate displays a sizable, significant, negative coefficient, which implies that in regions where the unemployment rate is lower, LBE is higher. An increase in the unemployment rate of 5 percentage points is associated with a decrease in LBE of about 1.5\% for Start-ups.

As discussed in Section 2, when employment opportunities as dependent workers are scarce and people are attached to the native location, individuals may decide to create their own business, which could in principle explains LBE. Yet, the evidence in the first two Columns of Table 9 implies that LBE is higher in regions with more favorable labor market conditions. This suggests that the combination of poor labor market conditions and individuals' attachment to the native location can hardly explain LBE. Furthermore local businesses tend to be larger and more valuable than non-local ones, which further suggests that this explanation can not fully account for LBE. ${ }^{17}$

Columns 3 to 6 of Table 9 further analyze the relation between LBE and the local level of economic activity, by studying how LBE varies across Italian regions (North vs. South) and in relation to the Province level per capita GDP. Columns 3 and 4 provide evidence that LBE is close to zero in Southern Regions. Yet, it becomes positive and significant as we consider Italian main Islands (Sardinia and Sicily) and it further increases as we move towards the North. The regional breakdown roughly reproduces Italian disparities

\footnotetext{
${ }^{17}$ For example, firms created by locals would be less valuable if, in the model discussed in Section 2 , we had that $c_{f}=0$ and $\gamma \leq \beta$.
} 
in terms of economic activity, since Northern Regions are among the richest areas in the European Union while the opposite is true for Southern Regions. Overall the evidence suggests that LBE tends to be positively related to the level of economic activity.

Columns 5 and 6 provide further support to the claim by relating LBE to the Province level per capita GDP in $1970 .{ }^{18}$ The specific year is chosen because more than $70 \%$ of the sampled entrepreneurs started their activity after 1970. This allows us to better isolate the effect of exogenous variation in economic development on LBE and it reduces the risk of identifying the effects of entrepreneurial activity on local GDP, rather than the opposite. ${ }^{19}$ The results show that the interaction term between entrepreneurial status and per capita GDP is positive and significant which confirms that LBE is higher in more developed regions. Overall the positive relationship between LBE and economic activity (as measured by employment rates and GDP per capita) suggests that local entrepreneurship may play a role in creating persistent disparities in economic development.

\subsection{LBE and local entrepreneurial density}

In Table 10, we also relate LBE to the entrepreneurial density in the Province of residence. The idea is to investigate whether learning from other entrepreneurs could explain LBE. For each Province considered in SHIW, we compute the fraction of entrepreneurs over the population of residence in 1991, 1993 and 1995 and we proxy the degree of entrepreneurial density by taking the average figure over the three years. Results are reported in Columns 1 and 2. Moreover, using information derived from various ISTAT data collections, we also relate LBE to the ratio of firms in a Province to the population in the Province, in 1971. The year is sufficiently far away in time, so that most entrepreneurs in our sample had not set up their activity yet, which reduces reverse causality problems. Results are reported

\footnotetext{
${ }^{18}$ We use raw GDP per capita, rather than its logarithm, to make results comparable with Guiso et al. (2004a). Results remain unchanged when considering the logarithm of per capita GDP rather than its level.

${ }^{19}$ We also tried considering earlier years and an average over 1965-1975. The results are roughly unchanged; yet, earlier data include missing values and their reliability is somewhat reduced.
} 
in Column 3. Our findings show that there exist a positive relation between LBE and the density of entrepreneurial activities. Yet, the effect is modest in size and not robust. For example after controlling for individual characteristics in Column 2, the interaction term between the entrepreneurial status variable and our measure of entrepreneurial density is not significantly different from zero. This suggests that technological spill-overs and learning from other entrepreneurs play little role in determining LBE.

To further investigate the role of technological spill-overs in determining LBE, we next relate LBE to the sectoral composition of local entrepreneurial activities. The idea is to test whether technological spill-overs are stronger in provinces where entrepreneurial activity is more specialized - say because the difference between $\gamma$ and $\beta$ in Section 2 is increasing in the degree of sectoral specialization of entrepreneurial activity. If technological spill-overs are the main explanation for LBE, then we would expect LBE to be increasing in the degree of specialization of entrepreneurial activities. We measure the level of entrepreneurial specialization in a specific sector and in a given Province, by computing the total number of entrepreneurs within a sector-Province cell over the total number of entrepreneurs in the Province, which is similar to the proxy used in Guiso and Schivardi (2003). We then take the average figure obtained over 1991, 1993 and $1995 .{ }^{20}$ In fact, we are unable to calculate the corresponding quantity for the date when the business venture was actually started. Yet, the geographical and sectoral distribution of the Italian districts have not drastically changed in the past decades, which makes us confident about this measure of sectoral specialization of entrepreneurial activities.

When we augment the regressions in Column 2 of Table 10 by including the indicator for the sectoral composition of entrepreneurial activities and its interaction with the entrepreneurial status variable, we find that the degree of entrepreneurial specialization does not play any significant role in accounting for LBE (see Column 4). We even find that

\footnotetext{
${ }^{20}$ Guiso and Schivardi (2003) use the number of entrepreneurs in a sector-Provice cell over the total population to measure entrepreneurial density. Our results do not vary when considering this alternative proxy.
} 
LBE is lower in Provinces with more specialized local entrepreneurial activities, although the effect is not statistically significant.

Guiso and Schivardi (2003) show that in areas with dense and specialized entrepreneurial environments, average total factor productivity tends to be higher. They argue that when more entrepreneurs work within a given sector and geographical area, people have higher chances of acquiring specific entrepreneurial skills. ${ }^{21}$ Although the authors do not directly address the question of why LBE may emerge, their evidence could suggest that technological spill-overs and entrepreneurial learning may explain LBE. Our findings however provide little support to this explanation.

\section{The role of financial markets}

It is well documented that funds' provision is an important concern in the decision to become entrepreneur. As discussed in the introduction, there are several reasons why locals could have a better access than non-locals to local credit markets. If firms also have to locate close to their financiers to obtain credit, this mechanism could explain why $c_{f}$ (in Section 2) is positive and why LBE emerges. We now investigate the role of financial markets in determining LBE. We start documenting that local firms are able to obtain greater financing per unit of capital invested. Then we construct an index of local financial development and we relate it to LBE, the probability of being an entrepreneur, and to firm's size.

\subsection{Preliminary evidence}

Table 11 documents that firms created by locals are able to obtain greater financing per unit of capital invested, than firms created by non-locals. We consider the sample of start-ups entrepreneurs and we regress the ratio of bank debts to firm's capital on the

\footnotetext{
${ }^{21}$ A closely related strand of literature focuses on knowledge and R\&D spill-overs and location decisions, suggesting that business ventures tend to be concentrated in locations specialized in given production activities (see e.g. Ellison and Glaser (1997)).
} 
dummy for being a local plus the following controls: individuals' gender, age, familial status, number of children, job tenure, average weekly hours worked, wealth (levels and squared), total household income; indicators for the size of the city or town where the individual lives; and dummies for educational achievements, less than full year jobs, sector of occupation, calendar years and for living in one of the five macro regions. Bank debts are measured in SHIW as short term (within 18 months) debts pertaining to the business activity towards banks and other financial institutions.

We find that the dummy identifying local individuals displays a positive and significant coefficient. Given average values for the bank debt-capital ratio, this implies that local entrepreneurs obtain $45 \%$ more financing per unit of capital invested than non-local entrepreneurs.

\subsection{An index of local financial development}

To further investigate the role of financial markets, we follow Guiso et al. (2004a) in constructing a measure of local financial development. We exploit information collected in SHIW about households' access to credit. SHIW asks households to report whether they have been denied credit or have been discouraged from applying for a loan. We use this information to create an indicator which measures how easy it is to obtain credit in a given location.

To apply the methodology we should take a stand on what is the relevant local financial market. Ideally, we would like to construct Province level indicators as this would be consistent with the evidence discussed so far. Moreover, up to the '90s, banks could only open branches conditional on an authorization granted Province-by-Province by the Bank of Italy. Thus also from an economic point of view, the Province seems to be the natural unit of analysis. Yet, as documented in Guiso et al. (2004a), statistical considerations related to missing data suggest that regional indicators are more reliable. We therefore compute and report results obtained using both Province- and Region-level indicators.

To identify geographical differences in the supply of credit, we estimate the probability 
that a household, potentially interested in borrowing, is either rejected or discouraged from borrowing. To approximate the set of potential borrowers we pool together all households with some debt and those that we know have been denied credit or discouraged from applying for a loan. We then estimate a linear probability model for the likelihood that a household was rejected access to credit - i.e. it has either been denied or discouraged from applying. As controls we include: household income and wealth (linear and squared); number of people belonging to the household and number of children; household head's age, gender, marital status, educational achievement and job qualification; indicators for the size of the city or town where the household lives and calendar year dummies. Finally, we include dummy variables for either Provinces or Regions of residence which identify the local level of financial development. Region and Province dummies represent the conditional probability of being rejected credit in the corresponding location. We then use these conditional probabilities, to measure local financial development by computing the following indicator:

$$
\text { Kav }=1-\frac{\text { Conditional Probability of Rejection }}{\max \{\text { Conditional Probability of Rejection }\}}
$$

where Kav stands for capital availability. We denote Province- and Region-level credit availability by $K a v P$ and $K a v R$, respectively.

To support the validity of the indicator we report on three exercises. First, an F-test strongly rejects the null hypothesis that either the Province or the Regional dummies are all equal. Second, a test on whether dummies for Provinces within the same Region are equal leads to a rejection of the null hypothesis in only 2 Regions (corresponding to Lombardia and Toscana) out of 19. Finally, we checked that there exists a significant positive correlation between our Region-level indicator $(\operatorname{Kav} R)$ and the index derived in Guiso et al. (2004a). For example the simple correlation between the two indicators is .90 , and significant at the $1 \%$ level, while the Spearman-rank correlation is .79 and the null hypothesis that the two series are independent is strongly rejected with a p-value of .0001. We start using Provinces and Regions of residence, rather than that of birth, due 
to the fact that this information is missing in 1995. We document below that our findings are fully confirmed when using financial market indicators for the Regions of birth with the data coming only from the 1991 and 1993 waves of the survey.

One important concern regards the possibility that the index of local financial development simply captures clustering of individuals with similar characteristics that make them potentially good borrower. Alternatively, it could be that entrepreneurs tend to cluster in locations where production and goods' delivery is more efficient. In turn this tends to generate high demand for loans in these locations which makes the financial markets tighter and endogenously reduce the value of the index. To avoid these problems, we need to identify some exogenous variation in the supply of credit that affects local financial development.

Following Guiso et al. (2004a), we exploit Italian banking regulation changes occurred in 1936. After the banking crisis of 1930-31, the Italian Government approved in 1936 a law that imposed rigid limits on the ability of different types of credit institutions to open new branches and extend credit. As detailed in Guiso et al. (2004a), the number of branches in each Province in the '90s can be partly explained by the number and types of banks in 1936. We therefore instrument the Region-level indicator of financial development $(K a v R)$ with a set of variables describing the regional banking structure in 1936. These variables are: number of branches per million of inhabitants in the Region; share of branches of local banks; number of savings banks per million of inhabitants and number of cooperative banks per million of inhabitants. (Province-level indicators cannot be instrumented since we lack an analogous set of Province-level variables for the banking system in 1936). The proposed instruments explain more than $50 \%$ of the regional variation in credit availability as measured by $K a v R$ and they are quite unrelated to the level of economic development of the region at the time. Moreover, an F-Test strongly rejects the null of joint non-significance of the instruments. 


\subsection{LBE and local financial development}

If local credit can be more easily accessed by native individuals, we expect that the development of local financial markets benefit local entrepreneurs more than non-locals. We therefore envisage LBE to be increasing in the level of local financial development. Table 12 provides evidence supporting this prediction. We first exploit the Provincelevel variation in credit availability $(\mathrm{KavP})$ and its interaction with the dummy variable identifying the entrepreneurial status. Column 1 does not include any controls; Column 2, includes the previously detailed variables. We find that, once we control for the conditions of the local credit market, the raw difference between the fraction of local entrepreneurs and the share of local dependent workers is no longer significant. Yet, the interaction between the entrepreneurial status and the indicator for local financial development bears a positive and statistically significant coefficient: more developed local financial markets are associated with a larger LBE. Given the results in Column 2, moving from the least developed financial markets in the sample $(\operatorname{Kav} P=0)$ to the average value of the Provincelevel indicator $(\mathrm{KavP}=0.6)$ would move $\mathrm{LBE}$ from zero to 11 percentage points. LBE would further go up to 14 percentage points for the most financially developed region in the sample $(\operatorname{Kav} P=0.79)$. This suggests that credit availability in local financial markets can (almost fully) account for the emergence of LBE.

We repeat the same exercise exploiting Region-level variation in financial market development. This is done in Columns 3. The previous findings are fully confirmed: the interaction between the dummy variable identifying the entrepreneurial status and the index of local financial development exhibits a positive and statistically significant coefficient, while the raw difference between the share of local entrepreneurs and native dependent workers is no longer significant. Quantitatively, we find that moving from the least to the most developed local financial markets, as measured by KavR, would drive LBE from 0 up to 7 percentage points.

As previously discussed, a possible objection to the previous results is that the pro- 
posed indicators are correlated with unobserved determinants of LBE, or alternatively that causation runs from clustering of entrepreneurs to local financial development. We address this issue by instrumenting $\operatorname{Kav} R$ and its interaction with the dummy for Startups with the previously described set of variables characterizing the regional banking structure in 1936. The IV estimates reported in Columns 4 and 5 confirm the results obtained using OLS. The impact of local credit availability on LBE is now even larger and more statistically significant. Moving from the least to the most developed financial market would drive LBE from 0 to 11 percentage points. When we repeat the same analysis using instrumented indicators for Region of birth, the results remain broadly unchanged. Although the exclusion of 1995 causes a fall in sample size, the estimated impact of local financial development on LBE is as sizable as that obtained with the Region of residence, and strongly significant.

One caveat applies to our accounting exercise. Since financial market indicators are measured with error, we may be overestimating their power in explaining the emergence of LBE. Following Hall and Jones (1999), we address the problem in this way: define by $F$ and $\widehat{F}$ the true (unobserved) and the estimated financial development indicator, respectively. Let $\operatorname{corr}(F, \widehat{F}), \sigma_{F}$ and $\sigma_{\widehat{F}}$ denote the correlation between the two indices and the two associated coefficients of variation, respectively. Consider now that the square root of the ratio of the estimated OLS coefficient to the IV coefficient in Table 12 is $\operatorname{corr}(F, \widehat{F})$, i.e. the correlation between the true and estimated (with noise) financial market indicators; at the same time, $\operatorname{corr}(F, \widehat{F})=\sqrt{\frac{\sigma_{F}}{\sigma_{\widehat{F}}}}$. Given that we observe both $\operatorname{corr}(F, \widehat{F})$ and $\sigma_{\widehat{F}}$, we can then derive the coefficient of variation for the true financial market indicator $\left(\sigma_{F}\right)$ and repeat our accounting exercise using this measure. ${ }^{22}$ Once this is done, we still find that, in the most developed financial markets, LBE is as high as 6.5

\footnotetext{
${ }^{22}$ To be more precise, we first calculate the coefficient of variation of our index as equal to $\sigma_{\widehat{F}}=$ $\widehat{F}_{\max }-\widehat{F}_{\min }$. This is approximately equal to 0.6 (at the Region level). Then we valculate the true coefficient of variation $\sigma_{F}$ as equal to $\operatorname{corr}(F, \widehat{F})^{2} \sigma_{\widehat{F}}$. This is approximately 0.35 . Given that the financial development measure is built so that it assumes value zero for the least developed markets, 0.35 also corresponds to the true index for the most dynamic credit markets. This figure is then used to measure LBE in the most developed areas.
} 
percentage points for start-ups. This supports the previous conclusions.

\subsection{Further evidence on the effects of local financial develop- ment}

So far the evidence provides support to the claim that LBE arises because local entrepreneurs can exploit their personal networks and reputational capital to gain access to local credit markets. We next show that tighter financial markets stimulate entrepreneurship and that this effect only runs via local entrepreneurs. This further documents how the interaction between credit availability and social capital can determine LBE.

In Table 13 we estimate the effects of local financial development on the probability of being an entrepreneur. In Column 1, we only include Region-level indicators for credit availability $(\operatorname{Kav} R)$; in Columns 2, we also include its interaction with the dummy variable identifying local individuals. Finally, in Columns 3 and 4, we instrument the indicators of local financial development for Regions of residence and Regions of birth, respectively. The following controls are included in the regression: individuals' gender, age, educational achievement, familial status, and number of children; number of members in the household; year dummies; five macro region dummies; and a dummy for transfers from parents or relatives. ${ }^{23}$

When only the credit availability indicator is included in the regression, we find that the level of financial development exerts a positive and significant impact on the probability of being entrepreneurs. This confirms the findings by Guiso et al. (2004a). Yet, Columns 2 to 4 provide some new evidence about the channel whereby credit availability influences the chances of starting up a new business. When the interaction between the availability of credit and the dummy identifying local individuals is included in the specification, the coefficient attached to the indicator of local financial development completely looses its significance. Moreover, the interaction term displays a large, positive and sta-

\footnotetext{
${ }^{23}$ Following Guiso et al. (2004a) we do not control for wealth. Yet, our findings were confirmed when we added this control.
} 
tistically significant coefficient. For the average individual in Column 3, the probability of starting up a business increases by $35 \%$ when moving from the least to the most developed local financial market. The IV results, for both Regions of residence and Region of birth, confirm the finding that tighter financial markets stimulate entrepreneurship mainly by promoting local entrepreneurship. ${ }^{24}$

In Table 14, we also consider the effects of local financial development on the employment size of the firm, its capital stock and its capital intensity. Independently on whether the index of local financial development is instrumented, we always find that the interaction between the index of financial development and the dummy identifying local individuals is positive and statistically significant. This implies that local financial development affects the average size of firms and their capital intensity mainly by favoring local individuals. This provides further evidence for the claim that local financial development drives LBE.

\section{Conclusions}

In this paper, we have documented that the fraction of entrepreneurs who set up their business in the location where they were born is significantly higher than the corresponding fraction for dependent workers. We have referred to this difference as to a local bias in entrepreneurship (LBE). The magnitude of LBE remains unchanged when we confine our attention to new businesses (start-ups), which implies that LBE is not the plain result of the intergenerational transmission of entrepreneurial activities.

We have documented that LBE is larger for relatively big and valuable companies.

\footnotetext{
${ }^{24}$ We did not add the dummy identifying locals to our regressions. Simultaneously including the indicator of financial development, the dummy for native workers and their interaction tend to create collinearity problems. For example, when we include all variables, our findings are qualitatively confirmed, although the estimates of the specific coefficients are less precise. For the instrumented measures of financial development for Regions of residence, we find that: KavR has an estimated impact of -0.044 with a T-statistic of -0.34 ; the interaction term has a 0.114 coefficient with a 1.05 T-statistic; the Local dummy has a 0.012 impact with an 0.40 T-statistic. An F-test rejects the null that the interaction term and the Local dummy are jointly non significant with a p-value of 0.0069 .
} 
LBE is also higher in areas with low unemployment rates and high GDP per capita, which suggests that LBE may help perpetuating differences in technology and economic development. Interestingly, LBE is generally unrelated to how intense and specialized entrepreneurial activities are in the given location, which suggests that technological spillovers and learning from other local entrepreneurs could play little role in explaining LBE.

We have also found that firms created by locals are more valuable and bigger (in terms of capital and employment), operate with more capital intensive technologies, and are able to obtain greater financing per unit of capital invested than firms created by non-locals. We interpreted these findings by arguing that locals can better exploit the financial opportunities available in the region where they were born. In particular it could be that local banks have access to privileged information about local individuals; or it could be that, due to peer monitoring or local social pressure, the moral hazard problem associated with borrowing is less severe for local individuals that borrow from local banks. Either way, local individuals have a privileged access to financing in the region where they were born. If banks also require the financed entrepreneurial venture to be geographically close, say because this reduces monitoring costs, this mechanism can generate LBE. By using the measure of local financial development originally proposed by Guiso et al. (2004a), we found that LBE is increasing in the degree of local financial development, which further supports the previous interpretation. Since business creation is a primary source of technological adoption and innovation, this mechanism can help explaining how differences in local financial development cause persistent disparities in entrepreneurial activity, technology and income across regions and countries. Under this view, technological catching up requires both the nurturing of local entrepreneurship and well developed local financial markets. 


\section{A Derivation of (4)}

To derive (4) we start calculating the total number of individuals that abandon the location of birth. This is equal to

$$
M=(1-\alpha)(1-\rho)
$$

since individuals move only if they are both unattached and specialized in the sector where the native location fails to have a natural advantage. Since in equilibrium every location is populated by a measure one of individuals the number of stayers is equal to

$$
S=1-M=\alpha+(1-\alpha) \rho .
$$

The total number of local entrepreneurs is equal to

$$
S_{e}=\rho \gamma(1-\bar{w}+Z)+\alpha(1-\rho) \beta(1-\underline{w})
$$

since the proportion $\rho$ of individuals that are specialized in the sector where the location has its natural advantage never move and they become entrepreneurs only if they obtain an entrepreneurial idea of value $\nu>\bar{w}-Z+c_{f}$, whose joint probability is the first term in the right-hand side of (6). Conversely, individuals that are specialized in the sector where the native location fails to have a natural advantage, stay only if they are attached and they become entrepreneurs if the value of their entrepreneurial idea is greater than $\underline{w}$, whose probability corresponds to the second term in (6).

The total number of foreign entrepreneurs is equal to

$$
M_{e}=(1-\alpha)(1-\rho) \beta\left(1-\bar{w}+Z-c_{f}\right)
$$

since an entrepreneur moves only if she is unattached, she is specialized in the sector where the native location fails to have a natural advantage and she has an entrepreneurial idea of value $\nu>\bar{w}-Z+c_{f}$. As a result the total number of businesses created in the location is equal to

$$
\begin{aligned}
N_{e}= & S_{e}+M_{e}=\rho \gamma(1-\bar{w}+Z)+\alpha(1-\rho) \beta(1-\underline{w}) \\
& +(1-\alpha)(1-\rho) \beta\left(1-\bar{w}+Z-c_{f}\right),
\end{aligned}
$$

which together with (6) allow to express the fraction of local entrepreneurs over the total number of entrepreneurs as equal to

$$
s_{e}=\frac{S_{e}}{N_{e}}
$$


By a complementary logic we obtain that the total number of workers who work in the location where they were born is equal to

$$
S_{w}=\rho[(1-\gamma)+\gamma(\bar{w}-Z)]+\alpha(1-\rho)[(1-\beta)+\beta \underline{w}]
$$

while the total number of non-local workers is given by

$$
M_{w}=(1-\alpha)(1-\rho)\left[(1-\beta)+\beta\left(\bar{w}-Z+c_{f}\right)\right],
$$

so that the total number of workers in a given location can be expressed as

$$
N_{w}=S_{w}+M_{w}
$$

The fraction of local workers over the total number of workers in the location can then be expressed as equal to

$$
s_{w}=\frac{S_{w}}{N_{w}}
$$

After using (7) and (8) and after some algebra, (4) immediately follows.

\section{B Data classifications and definitions}

Our data are drawn from the Survey of Households Income and Wealth (SHIW). SHIW contains detailed information on household composition, age, education, labour market variables, incomes (for individuals and households), savings, consumption and wealth. Some information on credit, transfers, insurance, inter-generational comparisons and expenditures are available just in some selected years. The survey is conducted by the Bank of Italy and was started in the '60s, for cross-sectional analysis. Since more recent years, the Survey has gradually moved towards a rotating panel structure and is usually administered every two years. The latest releases include about 8000 households (24000 individuals), located in 300 Italian municipalities. We use 1991, 1993 and 1995 waves and retain in our sample only working heads of households aged between 18 and 65 . The following variables were used in our analysis:

Gender: Gender of head of household (male, female).

Age: Age of head of household; this was derived as the difference between the year of the survey and the year of birth.

Familial Status: Familial status of head of household; it includes: 1) married/cohabitant, 2) single, 3) separated/divorced, 4) widow/widower. From this information we constructed a dummy variable identifying a married individual as one replying yes to 1). 
Size of Household: Total number of people living with the household.

Number of Children: Number of children living in the household.

Intergenerational transfers: A binary variable identifying whether the head of household received any monetary transfers from parents or relatives (cohabitant and noncohabitant).

Educational achievements: Educational attainments of head of household; five different categories are considered in SHIW: no schooling, elementary school, junior high school, high school, B.A./B.S., specialization.

Job Qualification: Qualification at the level of primary activity of head of household; SHIW information includes: blue collar, white collar, professional, entrepreneur, selfemployed/craftsman, worker of family firm, manager-partner of a society.

Household income: Total household net disposable income as classified in SHIW; it includes: income from employment, pensions and transfers, self-employment income and capital income.

Household wealth: Net real wealth as classified in SHIW; it is defined as total real assets minus total financial liabilities.

Business Bank Debt: Short term (within 18 months) debts towards banks and other financial institutions, relating to the running of the business activity (available for entrepreneurs only).

Firm's Market Value: Estimated market value of the participation in the venture, in case of selling it (available for entrepreneurs only). For manager-partners of societies, this is the actual value of the individuals' participation in the business.

Employment Size: Total employment at the firm, defined as the total number of employees plus non-dependent head/owner of the business.

Capital Stock: Firm capital as proxied by capital depreciation ("Ammortamenti" in the Survey); this information is not available for manager-partners of society.

Capital-Labor ratio: Capital stock, as proxied by "Ammortamenti" divided by the firm's employment size. 
Macro Region Dummies: Dummies identifying household macro-regions of residence; include: north-west, north-east, centre, south, main islands.

Size of City/Town: Number of inhabitants in the municipality where the household resides; in SHIW these are clustered into the following values: $<20.000,20.000-40.000$, 40.000-500.000, >500.000.

Hours Worked Per Week: Average number of hours worked per week, including extra-time, over the year prior to the Survey.

Share of Firms, 1971: Total number of firms operating in a Province over the total population of the Province; both data for 1971. Information collected by ISTAT; available at www.istat.it.

Share of Entrepreneurs: Number of entrepreneurs working in a Province over number of individuals living in the Province; derived from SHIW. Average figure for 1991, 1993 and 1995.

Capital Availability, Province and Region: Index of local financial development at the Province and Region Level; see body text and Guiso at al. (2004a) for details about the construction of these indices. 


\section{References}

[1] Acs, Z. and Audretsch, D., (2003) Handbook of Entrepreneurship Research, Kluwer Academic Publishers.

[2] Acs, Z., Audretsch, D., Braunerhjelm, P. and Carlsson, B. (2004), "The Missing Link: the Knowledge Filter and Entrepreneurship in Endogenous Growth", CEPR DP 4783

[3] Alba-Ramirez, A. (1994), "Self-Employment in the Midst of Unemployment: the Case of Spain and the United States", Applied Economics 26, 189-204.

[4] Arnott, R. and Stiglitz, J. (1991), "Moral Hazard and Nonmarket Institutions: Dysfunctional Crowding Out of Peer Monitoring?", American Economic Review 81, 179190.

[5] Blanchflower D.G.and Oswald, A.J. (1998), "What makes an Entrepreneur?", Journal of Labor Economics 16(1), 26-60.

[6] Borjas, G.J. (1987), "Self-Selection and the Earnings of Immigrants", American Economic Review 77(4), 531-553.

[7] Borjas, G.J., Bronars, S.G. and Trejo, S.J. (1992), "The Assimilation and Earnings of Young Internal Migrants", Review of Economics and Statistics, 74(1), 170-75.

[8] Chelli, F. and Rosti, L. (1998), "Una analisi sui Flussi del Mercato del Lavoro: l'Occupazione Indipendente", Politica Economica 3, 447-476.

[9] Ellison, G. and Glaser, E. (1997), "Geographic Concentration in U.S. Manufacturing Industries: A Dartboard Approach", Journal of Political Economy 105, 889-927.

[10] Evans, D.S. and Jovanovic, B. (1989), "An Estimated Model of Entrepreneurial Choice Under Liquidity Constraints", Journal of Political Economy 87(4), 808-827.

[11] Guiso, L. and Schivardi F. (2003), "Learning to be an Entrepreneur", Mimeo, Bank of Italy.

[12] Guiso, L., Sapienza, P. and Zingales, L. (2004a), "Does Local Financial Development Matters?" Quarterly Journal of Economics 119, 929-969.

[13] Guiso, L., Sapienza, P. and Zingales, L. (2004b), "The Role of Social Capital in Financial Development", American Economic Review 94, 526-556. 
[14] Hall, R. and Jones, C. (1999), "Why Do Some Countries Produce So Much More Output than Others?" Quarterly Journal of Economics, 83-116.

[15] Holtz-Eakin, D., Joulfaian, D. and Rosen, H.S. (1994), "Entrepreneurial Decisions and Liquidity Constraints", Rand Journal of Economics 25(2), 334-347.

[16] Lucas, R. (1979), "On the Size Distribution of Business Firms", Bell Journal of Economics, 9(2), 508-523.

[17] Lucas, R. (1990), "Why Doesn't Capital Flow from Rich to Poor Countries?" American Economic Review , Papers and Proceeding, 80(2), 97-96.

[18] Martinez-Granado, M. (2003), "Self-Employment and Labour Market Transitions: a Multiple State Model", CEPR DP 3661.

[19] Michelacci, C. (2003), "Low Returns to R\&D Due to the Lack of Entrepreneurial Skills", Economic Journal, 113(127), 207-225.

[20] OECD, (1992), OECD Employment Outlook 1992.

[21] OECD, (2000), OECD Employment Outlook 2000.

[22] Petersen, M. and Rajan, R. (2002), "Does Distance Still Matter?: The information Revolution in Small Business Lending", Journal of Finance 57, 2533-2570.

[23] Schumpeter, J. (1911), The Theory of Economic Development, Harvard University Press, Cambridge, Massachusetts.

[24] Williamson, S. (1987), "Costly Monitoring, Loan Contracts and Equilibrium Credit Rationing", Quarterly Journal of Economics, 136-145. 
Table 1: Descriptive Statistics

\begin{tabular}{|c|c|c|c|c|c|c|}
\hline \multirow[b]{2}{*}{ Variable } & \multicolumn{3}{|c|}{ 1991-1993 Sample } & \multicolumn{3}{|c|}{ 1991-1993-1995 Sample } \\
\hline & $\mathrm{N}$ & Mean & St.-Dev. & $\mathrm{N}$ & Mean & St.-Dev. \\
\hline Local & 8810 & .73 & .44 & 12841 & .74 & .44 \\
\hline Worker & 9068 & .74 & .44 & 13174 & .74 & .44 \\
\hline Blue collar & 9068 & .34 & .47 & 13174 & .34 & .47 \\
\hline White collar & 9068 & .40 & .49 & 13174 & .40 & .49 \\
\hline Entrepreneur & 9068 & .26 & .44 & 13174 & .26 & .44 \\
\hline Start-up1 & 9043 & .18 & .39 & 13149 & .19 & .39 \\
\hline Start-up2 & 9043 & .19 & .39 & 13149 & .20 & .40 \\
\hline Male & 9068 & .89 & .31 & 13174 & .89 & .32 \\
\hline Age & 9068 & 43.8 & 9.58 & 13174 & 43.8 & 9.53 \\
\hline Married & 9068 & .84 & .36 & 13174 & .84 & .36 \\
\hline Number of children & 9068 & 1.49 & 1.07 & 13174 & 1.48 & 1.07 \\
\hline No more than Primary School & 9068 & .25 & .43 & 13174 & .23 & .42 \\
\hline Junior High School & 9068 & .34 & .47 & 13174 & .34 & .47 \\
\hline High School & 9068 & .30 & .46 & 13174 & .32 & .47 \\
\hline At least B.A. & 9068 & .10 & .30 & 13174 & .10 & .31 \\
\hline Job Tenure & 8895 & 16.3 & 10.7 & 12898 & 16.7 & 10.9 \\
\hline Hours worked per week & 9019 & 41.8 & 9.76 & 13083 & 41.9 & 10.4 \\
\hline Employment Size of the Firm & 2343 & 3.73 & 16.4 & 3452 & 3.77 & 15.49 \\
\hline Firm Value & 2155 & 128500 & 382992 & 3209 & 129840 & 402174 \\
\hline Ammortamenti (Capital) & 2044 & 3114 & 6377 & 2837 & 3803 & 9248 \\
\hline Capital/Labour Ratio & 2022 & 1622 & 3143 & 2815 & 1876 & 4379 \\
\hline Bank Debits/Capital & 890 & 1.13 & 8.60 & 1341 & 1.14 & 7.54 \\
\hline Unemployment Rate & 9068 & .12 & .06 & 13174 & .12 & .07 \\
\hline GDP per Capita, 1970 & 9068 & 9.60 & 2.48 & 13174 & 9.63 & 2.47 \\
\hline Share of Entrepreneurs & 9068 & .12 & .04 & 13174 & .12 & .04 \\
\hline Share of Firms, 1971 & 9068 & .040 & .009 & 13174 & .040 & .009 \\
\hline Capital Availability, Province & 9068 & .602 & .122 & 13174 & .604 & .122 \\
\hline Capital Availability, Region & 9068 & .289 & .156 & 13174 & .292 & .156 \\
\hline
\end{tabular}

Note: Start-up include only entrepreneurs who declare having found their job by setting up their activity. Start-up 2 only counts entrepreneurs who did not find their job taking up parents' activities. Age and Job tenure are in years. Firm Value, Ammortamenti and Bank Debits are in thousands of liras. Employment Size of the Firm is defined as total number of employees plus non-dependent head/owner of the business. GDP in 1970 measured in millions of 1990 liras. Share of Entrepreneurs is the total number of entrepreneurs in a Province divided by the number of individuals living in the Province. Share of Firms in 1971 is the number of firms in a Province in 1971 over the population of the Province in 1971. 
Table 2: Size Distribution of Firms

\begin{tabular}{|c|c|c|c|c|}
\hline \multirow[b]{2}{*}{ Firm Size } & \multicolumn{2}{|c|}{$\begin{array}{l}\text { SHIW Sample } \\
\text { (Frequency) }\end{array}$} & \multicolumn{2}{|c|}{$\begin{array}{c}\text { Population, } 1991 \text { Census } \\
\text { (Frequency) }\end{array}$} \\
\hline & All Firms & $\begin{array}{c}\text { Without agricultural } \\
\text { firms } \\
\end{array}$ & All Firms & $\begin{array}{c}\text { Without agricultural } \\
\text { firms } \\
\end{array}$ \\
\hline $1-2$ & 68.3 & & 70 & \\
\hline $3-5$ & 20.6 & 94.3 & 18.7 & 93.2 \\
\hline $6-9$ & 5.6 & & 5.6 & \\
\hline $10-19$ & 3.3 & 3.3 & 3.7 & 3.3 \\
\hline$\geqslant 20$ & 2.1 & 2.4 & 2.2 & 2.2 \\
\hline
\end{tabular}

Source: SHIW 1991, 1993 and 1995 and 1991 ISTAT Census of Italian firms and Services.

Note: When agriculture is excluded, a finer breakdown of firm size categories is not available. 
Table 3: Regional Distribution of Firms

\begin{tabular}{|c|c|c|c|c|}
\hline \multirow[t]{2}{*}{ Region } & \multicolumn{2}{|c|}{$\begin{array}{l}\text { SHIW Sample } \\
\text { (Frequency) }\end{array}$} & \multicolumn{2}{|c|}{$\begin{array}{c}\text { Population, } 1991 \text { Census } \\
\text { (Frequency) }\end{array}$} \\
\hline & All Firms & $\begin{array}{l}\text { Without agricultural } \\
\text { firms }\end{array}$ & All Firms & $\begin{array}{c}\text { Without agricultural } \\
\text { firms }\end{array}$ \\
\hline Piemonte & 8.41 & 8.68 & 9.19 & 8.2 \\
\hline Lombardia & 9.68 & 10.09 & 17.43 & 17.2 \\
\hline Trentino-Alto Adige & 2.41 & 2.38 & 1.95 & 1.9 \\
\hline Veneto & 5.36 & 5.44 & 9.16 & 9.1 \\
\hline Friuli-Venezia Giulia & 2.91 & 3.00 & 2.38 & 2.4 \\
\hline Liguria & 4.83 & 4.95 & 3.22 & 3.2 \\
\hline Emilia-Romagna & 8.91 & 8.85 & 9.31 & 9.3 \\
\hline Toscana & 7.08 & 7.33 & 8.08 & 8.1 \\
\hline Umbria & 3.57 & 3.61 & 1.55 & 1.6 \\
\hline Marche & 4.45 & 4.49 & 3.22 & 3.2 \\
\hline Lazio & 6.00 & 6.13 & 7.23 & 7.3 \\
\hline Abruzzo & 3.68 & 3.76 & 2.28 & 2.3 \\
\hline Molise & .82 & .78 & .54 & .5 \\
\hline Campania & 8.55 & 8.60 & 7.20 & 7.3 \\
\hline Puglia & 7.60 & 7.05 & 5.67 & 5.7 \\
\hline Basilicata & 1.46 & 1.31 & .93 & .9 \\
\hline Calabria & 3.35 & 3.26 & 2.68 & 2.7 \\
\hline Sicilia & 7.67 & 7.09 & 6.40 & 6.5 \\
\hline Sardegna & 3.23 & 3.18 & 2.57 & 2.6 \\
\hline
\end{tabular}

Source: SHIW 1991, 1993 and 1995 and 1991 ISTAT Census of Italian firms and Services. 
Table 4: Evidence on LBE - 1991 and 1993 only

\begin{tabular}{|c|c|c|c|c|c|c|c|c|}
\hline $\begin{array}{l}\text { Description } \\
\text { Depvar.: }\end{array}$ & $\begin{array}{c}1 \\
\text { Local }\end{array}$ & $\begin{array}{c}2 \\
\text { Local }\end{array}$ & $\begin{array}{c}3 \\
\text { Local }\end{array}$ & $\begin{array}{c}4 \\
\text { Local }\end{array}$ & $\begin{array}{c}5 \\
\text { Local }\end{array}$ & $\begin{array}{c}6 \\
\text { Local }\end{array}$ & $\begin{array}{c}7 \\
\text { Local }\end{array}$ & $\begin{array}{c}8 \\
\text { Local }\end{array}$ \\
\hline Constant & $\begin{array}{l}0.716^{* * *} \\
(0.005)\end{array}$ & $\begin{array}{l}0.733^{* * *} \\
(0.032)\end{array}$ & $\begin{array}{l}0.716^{* * *} \\
(0.005)\end{array}$ & $\begin{array}{l}0.734^{* * *} \\
(0.032)\end{array}$ & $\begin{array}{l}0.716^{* * *} \\
(0.005)\end{array}$ & $\begin{array}{l}0.733^{* * *} \\
(0.032)\end{array}$ & $\begin{array}{l}0.707^{* * *} \\
(0.029)\end{array}$ & $\begin{array}{l}0.705^{* * *} \\
(0.029)\end{array}$ \\
\hline Blue Collar & & & & & & & $\begin{array}{l}0.024^{*} \\
(0.013)\end{array}$ & $\begin{array}{l}0.025^{*} \\
(0.013)\end{array}$ \\
\hline Entrepreneur & $\begin{array}{l}0.075^{* * *} \\
(0.011)\end{array}$ & $\begin{array}{l}0.067^{* * *} \\
(0.010)\end{array}$ & & & & & & \\
\hline Start-up1 & & & $\begin{array}{l}0.073^{* * *} \\
(0.012)\end{array}$ & $\begin{array}{l}0.061^{* * *} \\
(0.012)\end{array}$ & & & $\begin{array}{l}0.073^{* * *} \\
(0.014)\end{array}$ & \\
\hline Start-up2 & & & & & $\begin{array}{l}0.066^{* * *} \\
(0.011)\end{array}$ & $\begin{array}{l}0.059^{* * *} \\
(0.011)\end{array}$ & & $\begin{array}{l}0.071^{* * *} \\
(0.013)\end{array}$ \\
\hline Controls & No & Yes & No & Yes & No & Yes & Yes & Yes \\
\hline N.of Obs. & 8404 & 8404 & 8385 & 8385 & 8385 & 8385 & 8385 & 8385 \\
\hline R-Squared & 0.735 & 0.765 & 0.735 & 0.765 & 0.735 & 0.765 & 0.765 & 0.765 \\
\hline
\end{tabular}

Note: In column 1 to 6 , the reference individual is a Worker. In column 7 to 8 she is a White Collar Worker. The controls are: Individuals' gender, age, familial status, number of children and four educational achievement dummies, 1991 and 1993 year dummies, 5 Macro Region Dummies and in the regressions with start-ups a dummy variable for non start-ups entrepreneurs. All regressions use OLS. Robust S.E. in parentheses with $\mathrm{p}$-value $<0.10{ }^{*}$, $\mathrm{p}$-value $<0.05={ }^{* *}$, p-value $<0.01={ }^{* * *}$. 
Table 5: Evidence on LBE - including 1995

\begin{tabular}{|c|c|c|c|c|c|c|}
\hline Description & 1 & 2 & 3 & 4 & 5 & 6 \\
\hline Depvar.: & Local & Local & Local & Local & Local & Local \\
\hline Constant & $\begin{array}{l}0.724^{* * *} \\
(0.004)\end{array}$ & $\begin{array}{l}0.799^{* * *} \\
(0.026)\end{array}$ & $\begin{array}{l}0.724^{* * *} \\
(0.005)\end{array}$ & $\begin{array}{l}0.797^{* * *} \\
(0.026)\end{array}$ & $\begin{array}{l}0.769^{* * *} \\
(0.029)\end{array}$ & $\begin{array}{c}0.802^{* * *} \\
(0.026)\end{array}$ \\
\hline Blue Collar & & & & & $\begin{array}{l}0.024^{* *} \\
(0.011)\end{array}$ & \\
\hline Entrepreneur & $\begin{array}{l}0.072^{* * *} \\
(0.009)\end{array}$ & $\begin{array}{l}0.063^{* * *} \\
(0.009)\end{array}$ & & & & \\
\hline Start-up2 & & & $\begin{array}{l}0.063^{* * *} \\
(0.009)\end{array}$ & $\begin{array}{l}0.056^{* * *} \\
(0.009)\end{array}$ & $\begin{array}{l}0.068^{* * *} \\
(0.011)\end{array}$ & $\begin{array}{c}0.053^{* * *} \\
(0.009)\end{array}$ \\
\hline Start-up $2 \times$ & & & & & & $0.700^{*}$ \\
\hline Geographical Difference & & & & & & $(0.376)$ \\
\hline Geographical Difference & & & & & & $\begin{array}{c}0.369^{*} \\
(0.216)\end{array}$ \\
\hline Controls & No & Yes & No & Yes & Yes & Yes \\
\hline N.of Obs. & 12232 & 12232 & 12213 & 12213 & 12213 & 12213 \\
\hline R-Squared & 0.742 & 0.772 & 0.742 & 0.772 & 0.772 & 0.772 \\
\hline
\end{tabular}

Note: In column 1 to 4, the reference individual is a Worker. In column 5 she is a White Collar Worker. The controls are: Individuals' gender, age, familial status, number of children and four educational achievement dummies, 1991 and 1993 year dummies and 5 Macro Region Dummies. Geographical Difference is the difference between the regional distribution of firms in ISTAT and SHIW. All regressions use OLS. Robust S.E. in parentheses with p-value $<0.10={ }^{*}$, p-value $<0.05={ }^{* *}$, p-value $<0.01=* * *$. 
Table 6: LBE by Firm Size

\begin{tabular}{|c|c|c|c|c|}
\hline Description & 1 & 2 & 3 & 4 \\
\hline Depvar.: & Local & Local & Local & Local \\
\hline \multicolumn{5}{|l|}{ A. Employment Size } \\
\hline Constant & $\begin{array}{l}0.724^{* * *} \\
(0.005)\end{array}$ & $\begin{array}{l}0.799^{* * *} \\
(0.026)\end{array}$ & $\begin{array}{l}0.725^{* * *} \\
(0.005)\end{array}$ & $\begin{array}{l}0.799^{* * *} \\
(0.026)\end{array}$ \\
\hline Start-up2 & $\begin{array}{l}0.044^{* * *} \\
(0.012)\end{array}$ & $\begin{array}{l}0.033^{* * *} \\
(0.011)\end{array}$ & $\begin{array}{l}0.056^{* * *} \\
(0.010)\end{array}$ & $\begin{array}{l}0.047^{* * *} \\
(0.009)\end{array}$ \\
\hline Entrepreneur $\times$ & $0.046^{* * *}$ & $0.058^{* * *}$ & & \\
\hline Employing more than one individual & $(0.017)$ & $(0.016)$ & & \\
\hline Entrepreneur $\times$ & & & $0.043^{*}$ & $0.059^{* * *}$ \\
\hline Employing more than five individual & & & $(0.024)$ & $(0.023)$ \\
\hline Controls & No & Yes & No & Yes \\
\hline N.of Obs. & 12177 & 12177 & 12177 & 12177 \\
\hline R-Squared & 0.742 & 0.772 & 0.742 & 0.771 \\
\hline \multicolumn{5}{|l|}{ B. Market Value } \\
\hline Constant & $\begin{array}{l}0.725^{* * *} \\
(0.005)\end{array}$ & $\begin{array}{l}0.798^{* * *} \\
(0.027)\end{array}$ & $\begin{array}{l}0.725^{* * *} \\
(0.005)\end{array}$ & $\begin{array}{l}0.799^{* * *} \\
(0.027)\end{array}$ \\
\hline Start-up2 & $\begin{array}{l}0.045^{* * *} \\
(0.013)\end{array}$ & $\begin{array}{l}0.038^{* * *} \\
(0.012)\end{array}$ & $\begin{array}{l}0.056^{* * *} \\
(0.010)\end{array}$ & $\begin{array}{l}0.049^{* * *} \\
(0.009)\end{array}$ \\
\hline Start-up $2 \times$ & $0.038^{* *}$ & $0.038^{* *}$ & & \\
\hline Firm value greater than the median & $(0.018)$ & $(0.012)$ & & \\
\hline $\begin{array}{l}\text { Start-up2 } \times \\
\text { Firm value greater than top decile }\end{array}$ & & & $\begin{array}{l}0.046 \\
(0.029)\end{array}$ & $\begin{array}{l}0.052^{*} \\
(0.030)\end{array}$ \\
\hline Controls & No & Yes & No & Yes \\
\hline N.of Obs. & 11983 & 11983 & 11983 & 11983 \\
\hline R-Squared & 0.741 & 0.770 & 0.741 & 0.770 \\
\hline
\end{tabular}

Note: The reference individual is a Worker. Results for Start-up entrepreneurs only. The controls are: Individuals' gender, age, familial status, number of children and four educational achievement dummies, 1991 and 1993 year dummies, 5 Macro Region dummy variables and a dummy variable for non Start-ups entrepreneurs. All regressions use OLS. Robust S.E. in parentheses with p-value $<0.10={ }^{*}$, p-value $<0.05$ $=* *$, p-value $<0.01=* * *$. 
Table 7: Firm's size of Locals and Non-Locals Start-ups

\begin{tabular}{|c|c|c|c|c|c|c|}
\hline Description & 1 & 2 & 3 & 4 & 5 & 6 \\
\hline Depvar: & $\begin{array}{l}\text { Employment } \\
\text { Size of Firm }\end{array}$ & $\begin{array}{l}\text { Employment } \\
\text { Size of Firm }\end{array}$ & Capital & Capital & $\begin{array}{l}\mathrm{K} / \mathrm{L} \\
\text { ratio }\end{array}$ & $\begin{array}{l}\mathrm{K} / \mathrm{L} \\
\text { ratio }\end{array}$ \\
\hline Local & $\begin{array}{l}1.192^{* *} \\
(0.597)\end{array}$ & $\begin{array}{l}1.409 * * \\
(0.634)\end{array}$ & $\begin{array}{l}1391^{* * *} \\
(327)\end{array}$ & $\begin{array}{l}1540^{* * *} \\
(394)\end{array}$ & $\begin{array}{l}624^{* * * *} \\
(187)\end{array}$ & $\begin{array}{l}715^{* * *} \\
(262)\end{array}$ \\
\hline Controls & No & Yes & No & Yes & No & Yes \\
\hline N.of Obs. & 2333 & 2256 & 1919 & 1848 & 1899 & 1830 \\
\hline R-Squared & 0.001 & 0.029 & 0.004 & 0.056 & 0.003 & 0.048 \\
\hline
\end{tabular}

Note: The regression is ran on the sample of Start-up entrepreneurs. The controls are: individuals' gender, age, familial status, number of children, job tenure, average hours worked per week; indicators for the size of the city or town where the individual lives; dummies for educational achievement, less than full year jobs, sector of occupation and calendar years; 5 Macro Region dummy variables and a dummy variable for non Start-ups entrepreneurs. All regressions use OLS. Robust S.E. in parentheses with $\mathrm{p}$-value $<0.10=*$, p-value $<0.05={ }^{* *}$, p-value $<0.01=* * *$. 
Table 8: Labor Income of Local and Non-Local Dependent Workers

\begin{tabular}{|c|c|c|c|c|c|c|}
\hline $\begin{array}{l}\text { Description } \\
\text { Depvar.: }\end{array}$ & $\begin{array}{c}1 \\
\text { Total } \\
\text { Wage bill } \\
\end{array}$ & $\begin{array}{c}2 \\
\text { Total } \\
\text { Wage bill }\end{array}$ & $\begin{array}{c}3 \\
\text { Total } \\
\text { Wage bill }\end{array}$ & $\begin{array}{c}4 \\
\text { Net } \\
\text { Wages } \\
\end{array}$ & $\begin{array}{c}5 \\
\text { Net } \\
\text { Wages } \\
\end{array}$ & $\begin{array}{c}6 \\
\text { Net } \\
\text { Wages }\end{array}$ \\
\hline Local & $\begin{array}{l}-2594^{* * *} \\
(304)\end{array}$ & $\begin{array}{l}-908^{* *} \\
(268)\end{array}$ & & $\begin{array}{l}-2544^{* *} \\
(297)\end{array}$ & $\begin{array}{l}-946^{* *} \\
(262)\end{array}$ & \\
\hline Local $\times$ White Collar & & & $\begin{array}{l}-1757^{* *} \\
(407)\end{array}$ & & & $\begin{array}{l}-1793^{* *} \\
(397)\end{array}$ \\
\hline Local $\times$ Blue Collar & & & $\begin{array}{l}249 \\
(233)\end{array}$ & & & $\begin{array}{l}208 \\
(225)\end{array}$ \\
\hline White Collar. & & & $\begin{array}{l}5702^{* *} \\
(397)\end{array}$ & & & $\begin{array}{l}5583^{* *} \\
(382)\end{array}$ \\
\hline Controls & No & Yes & Yes & No & Yes & Yes \\
\hline N.of Obs. & 9434 & 9213 & 9213 & 9434 & 9213 & 9213 \\
\hline R-Squared & 0.009 & 0.402 & 0.417 & 0.009 & 0.403 & 0.418 \\
\hline
\end{tabular}

Note: The regression is ran on the sample of dependent workers. The controls are: individuals' gender, age, familial status, number of children, job tenure, average hours worked per week; indicators for the size of the city or town where the individual lives; dummies for less than full year jobs, educational achievement, sector of occupation and calendar years; 5 Macro Region dummy variables; and current regional unemployment rates. All regressions use OLS. Robust S.E. in parentheses with p-value $<0.10=$ $*$, p-value $<0.05=* *$, p-value $<0.01=* * *$. 
Table 9: LBE and Local Economic Development

\begin{tabular}{|c|c|c|c|c|c|c|}
\hline Description & 1 & 2 & 3 & 4 & 5 & 6 \\
\hline Depvar.: & Local & Local & Local & Local & Local & Local \\
\hline Constant & $\begin{array}{c}0.502^{* * *} \\
(0.070)\end{array}$ & $\begin{array}{c}0.770^{* * *} \\
(0.066)\end{array}$ & $\begin{array}{l}0.899 * * * \\
(0.006)\end{array}$ & $\begin{array}{l}0.989 * * * \\
(0.026)\end{array}$ & $\begin{array}{l}1.325^{* * *} \\
(0.058)\end{array}$ & $\begin{array}{l}1.314^{* * *} \\
(0.118)\end{array}$ \\
\hline Start-up2 & $\begin{array}{l}0.110^{* * *} \\
(0.026)\end{array}$ & $\begin{array}{l}0.103^{* * *} \\
(0.022)\end{array}$ & $\begin{array}{l}0.017 \\
(0.013)\end{array}$ & $\begin{array}{l}0.016 \\
(0.013)\end{array}$ & $\begin{array}{l}-0.025 \\
(0.032)\end{array}$ & $\begin{array}{l}-0.024 \\
(0.031)\end{array}$ \\
\hline $\begin{array}{l}\text { Start-up } 2 \times \\
\text { Unemployment rate }\end{array}$ & $\begin{array}{l}-0.397^{* * *} \\
(0.150)\end{array}$ & $\begin{array}{l}-0.360^{* * *} \\
(0.125)\end{array}$ & & & & \\
\hline Unemployment rate & $\begin{array}{l}1.744^{* * *} \\
(0.234)\end{array}$ & $\begin{array}{r}0.309 \\
(0.401)\end{array}$ & & & & \\
\hline $\begin{array}{l}\text { Start-up } 2 \times \\
\text { Living in the North }\end{array}$ & & & $\begin{array}{l}0.064^{* * *} \\
(0.022)\end{array}$ & $\begin{array}{l}0.071^{* * *} \\
(0.021)\end{array}$ & & \\
\hline $\begin{array}{l}\text { Start-up } 2 \times \\
\text { Living in the Centre }\end{array}$ & & & $\begin{array}{l}0.043^{*} \\
(0.025)\end{array}$ & $\begin{array}{l}0.043^{*} \\
(0.025)\end{array}$ & & \\
\hline $\begin{array}{l}\text { Start-up } 2 \times \\
\text { Living in the Islands }\end{array}$ & & & $\begin{array}{l}0.049^{*} \\
(0.022)\end{array}$ & $\begin{array}{l}0.049 * \\
(0.023)\end{array}$ & & \\
\hline $\begin{array}{l}\text { Start-up2 } \times \\
\text { Province GDP in } 1970\end{array}$ & & & & & $\begin{array}{l}0.008^{* *} \\
(0.004)\end{array}$ & $\begin{array}{l}0.008^{* *} \\
(0.003)\end{array}$ \\
\hline Province GDP in 1970 & & & & & $\begin{array}{l}-0.062^{* * *} \\
(0.007)\end{array}$ & $\begin{array}{l}-0.051^{* * *} \\
(0.011)\end{array}$ \\
\hline Controls & No & Yes & No & Yes & No & Yes \\
\hline N.of Obs. & 12213 & 12213 & 12213 & 12213 & 12213 & 12213 \\
\hline R-Squared & 0.759 & 0.772 & 0.764 & 0.765 & 0.770 & 0.776 \\
\hline
\end{tabular}

Note: The reference individual is a worker; results for Start-up entrepreneurs only. The controls are: Individuals' gender, age, family status, number of children and four dummies for educational achievements, 1991 and 1993 year dummies and 5 Macro Region dummy variables and a dummy variable for non Start-ups entrepreneurs. Regional Unemployment Rates are averages over the years 1991, 1993 and 1995. All regressions use OLS. Cluster Adjusted S.E. in parentheses with p-value $<0.10={ }^{*}$, p-value $<0.05=$ ${ }^{* *}, \mathrm{p}$-value $<0.01=* * *$. 
Table 10: LBE and Local Entrepreneurial Density

\begin{tabular}{|c|c|c|c|c|}
\hline Description & 1 & 2 & 3 & 4 \\
\hline Depvar.: & Local & Local & Local & Local \\
\hline Constant & $\begin{array}{l}0.772^{* * *} \\
(0.095)\end{array}$ & $\begin{array}{l}0.751^{* * *} \\
(0.076)\end{array}$ & $\begin{array}{c}0.754^{* * *} \\
(0.141)\end{array}$ & $\begin{array}{c}0.745^{* * *} \\
(0.052)\end{array}$ \\
\hline Start-up2 & $\begin{array}{l}0.014 \\
(0.031)\end{array}$ & $\begin{array}{l}0.016 \\
(0.032)\end{array}$ & $\begin{array}{l}-0.020 \\
(0.042)\end{array}$ & $\begin{array}{c}0.033 \\
(0.038)\end{array}$ \\
\hline Start-up $2 \times$ Share of Entrepreneurs & $\begin{array}{l}0.407^{*} \\
(0.248)\end{array}$ & $\begin{array}{l}0.284 \\
(0.243)\end{array}$ & & $\begin{array}{c}0.287 \\
(0.284)\end{array}$ \\
\hline Share of Entrepreneurs & $\begin{array}{l}-0.396 \\
(0.568)\end{array}$ & $\begin{array}{l}0.335 \\
(0.385)\end{array}$ & & $\begin{array}{c}0.338 \\
(0.284)\end{array}$ \\
\hline Start-up2 $\times$ Share of Firms in 1971 & & & $\begin{array}{l}1.89^{*} \\
(1.08)\end{array}$ & \\
\hline Share of Firms in 1971 & & & $\begin{array}{c}0.95 \\
(2.89)\end{array}$ & \\
\hline Start-up2 $\times$ Sector Share of Entrepreneurs & & & & $\begin{array}{l}-0.084 \\
(0.077)\end{array}$ \\
\hline Sector Share of Entrepreneurs & & & & $\begin{array}{c}0.024 \\
(0.065)\end{array}$ \\
\hline Controls & No & Yes & Yes & Yes \\
\hline N.of Obs. & 12213 & 12213 & 12213 & 12213 \\
\hline R-Squared & 0.743 & 0.772 & 0.772 & 0.772 \\
\hline
\end{tabular}

Note: The reference individual is a worker; results for Start-up entrepreneurs only. The controls are: Individuals' gender, age, family status, number of children and four dummies for educational achievements, 1991 and 1993 year dummies, 5 Macro Region dummy variables and a dummy variable for non Start-ups entrepreneurs. Entrepreneurial Share is defined as the fraction of entrepreneurs in the population, in 1991, 1993 and 1995. Average Entrepreneurial Share is the average entrepreneurial share over 1991, 1993 and 1995. The share of Firms in the Population in 1971 was calculated using ISTAT data available online at www.istat.it. Sector Share of Entrepreneurs is defined as the fraction of entrepreneurs in a given Province that works in a specific sector. This is averaged over 1991, 1993 and 1995. Cluster Adjusted S.E. in parentheses with p-value $<0.10=*$, p-value $<0.05={ }^{* *}$, p-value $<0.01=* * *$. 
Table 11: Leverage of Local and Non-Local Firms

\begin{tabular}{lll}
\hline \hline $\begin{array}{l}\text { Description } \\
\text { Depvar: }\end{array}$ & \multicolumn{1}{c}{1} & \multicolumn{1}{c}{2} \\
& BankDebt & BankDebt \\
\hline Local & $0.827^{* *}$ & $0.570^{*}$ \\
& $(0.348)$ & $(0.311)$ \\
Controls & No & Yes \\
N.of Obs. & 1061 & 1040 \\
R-Squared & 0.002 & 0.042 \\
\hline
\end{tabular}

Note: Results for Start-up entrepreneurs only. Dependent Variable (BankDebt) is the amount of firm bank debits over the firm's capital as proxied by "ammortamenti". The controls are: individuals' gender, age, familial status, number of children, job tenure, average hours worked per week, wealth (levels and squared), total household income; indicators for the size of the city or town where the individual lives; dummies for educational achievements, less than full year jobs, sector of occupation, a full set of calendar year dummy variables; 5 Macro Region dummy variables and a dummy variable for non start-ups entrepreneurs. Robust S.E. in parentheses with p-value $<0.10={ }^{*}$, p-value $<0.05={ }^{* *}$, p-value $<0.01=$ $* * *$. 
Table 12: LBE and Local Financial Development

\begin{tabular}{|c|c|c|c|c|c|}
\hline Description & 1 & 2 & 3 & 4 & 5 \\
\hline Depvar.: & Local & Local & Local & Local & Local \\
\hline Constant & $\begin{array}{l}1.062^{* * *} \\
(0.099)\end{array}$ & $\begin{array}{l}0.877^{* * *} \\
(0.076)\end{array}$ & $\begin{array}{l}0.762^{* * *} \\
(0.064)\end{array}$ & $\begin{array}{l}0.777^{* * *} \\
(0.080)\end{array}$ & $\begin{array}{l}0.687^{* * *} \\
(0.117)\end{array}$ \\
\hline Start-up2 & $\begin{array}{l}-0.081 \\
(0.056)\end{array}$ & $\begin{array}{l}-0.056 \\
(0.053)\end{array}$ & $\begin{array}{l}0.015 \\
(0.018)\end{array}$ & $\begin{array}{l}-0.006 \\
(0.019)\end{array}$ & $\begin{array}{l}0.001 \\
(0.023)\end{array}$ \\
\hline Start-up $2 \times$ KavP & $\begin{array}{l}0.233^{* *} \\
(0.099)\end{array}$ & $\begin{array}{l}0.186^{* *} \\
(0.093)\end{array}$ & & & \\
\hline $\mathrm{KavP}$ & $\begin{array}{l}-0.558^{* * *} \\
(0.175)\end{array}$ & $\begin{array}{l}-0.135 \\
(0.097)\end{array}$ & & & \\
\hline Start-up2 $\times$ KavR & & & $\begin{array}{l}0.135^{* *} \\
(0.064)\end{array}$ & $\begin{array}{l}0.209^{* *} \\
(0.077)\end{array}$ & $\begin{array}{l}0.189^{*} \\
(0.098)\end{array}$ \\
\hline KavR & & & $\begin{array}{l}0.119 \\
(0.168)\end{array}$ & $\begin{array}{l}0.069 \\
(0.228)\end{array}$ & $\begin{array}{l}0.141 \\
(0.278)\end{array}$ \\
\hline Controls & No & Yes & Yes & Yes & Yes \\
\hline N.of Obs. & 12213 & 12213 & 12213 & 12213 & 8385 \\
\hline R-Squared & 0.748 & 0.772 & 0.772 & 0.772 & 0.765 \\
\hline
\end{tabular}

Note: The reference individual is a worker; results for Start-up entrepreneurs only. KavP and KavR are the index of Local Financial development (Capital Availability) at the Province and Region Level, respectively. KavP and KavR always refer to the region of residence, except in column 5 where it refers to region of birth. In this last case the sample concerns only with the 1991 and 1993 waves of SHIW. See body text and Guiso at al. (2004a) for details about the construction of these indices. The controls are: Individuals' gender, age, familial status, number of children and four dummies for educational achievements, 1991 and 1993 year dummies, 5 Macro Region dummy variables and a dummy variable for non Start-ups entrepreneurs. Columns 1-3 are OLS estimates. Columns 4-5 instrument KavR and its interaction by the structure of the Banking system in the region in 1936, see text. Cluster Adjusted S.E. in parentheses with p-value $<0.10={ }^{*}$, p-value $<0.05={ }^{* *}$, p-value $<0.01=*^{* *}$. 
Table 13: Probability of being Entrepreneur and Local Financial Development

\begin{tabular}{|c|c|c|c|c|}
\hline Description & 1 & 2 & 3 & 4 \\
\hline Depvar.: & Entr. Status & Entr. Status & Entr. Status & Entr. Status \\
\hline \multirow[t]{2}{*}{ Local $\times$ KavR } & & $0.137^{* * *}$ & $0.150 * * *$ & $0.147^{* *}$ \\
\hline & & $(0.047)$ & $(0.044)$ & $(0.056)$ \\
\hline \multirow[t]{2}{*}{ KavR } & $0.111^{* *}$ & -0.013 & -0.068 & -0.074 \\
\hline & $(0.053)$ & $(0.070)$ & $(0.087)$ & $(0.092)$ \\
\hline Controls & Yes & Yes & Yes & Yes \\
\hline N.of Obs & 12294 & 12231 & 12231 & 8466 \\
\hline R-Squared & 0.017 & 0.019 & 0.018 & 0.017 \\
\hline
\end{tabular}

Note: Dependent variable: creating a Start-up. The controls are: Individuals' gender, age, familial status, number of children, number of members in the household, dummies for educational achievements, a dummy for transfers from parents or relatives, 1991 and 1993 year dummies, 5 Macro Region Dummies, Years of Schooling. KavR is the index of Local Financial development (Capital Availability) at the Region Level. See body text and Guiso at al. (2004a) for more details. KavR always refers to the region of residence, except in column 4 where it refers to region of birth. In this last case the sample concerns only the 1991 and 1993 waves of SHIW. Columns 1-2 are OLS estimate. Columns 3-4 instrument KavR and its interaction by the structure of the Banking system in the region in 1936, see text. Cluster Adjusted S.E. in parentheses with p-value $<0.10=*$, p-value $<0.05=* *$, p-value $<0.01=* * *$. 


\section{Table 14: Firm's size and Local Financial Development}

\begin{tabular}{|c|c|c|c|c|c|c|}
\hline Description & 1 & 2 & 3 & 4 & 5 & 6 \\
\hline Depvar: & Empl.Size & Empl.Size & Capital & Capital & K/L Rat. & K/L Rat. \\
\hline \multirow[t]{2}{*}{ Local $\times$ KavR } & $18.0^{* *}$ & $16.4^{* *}$ & $6369^{*}$ & $6655^{* *}$ & $5281^{*}$ & $5120^{*}$ \\
\hline & $(7.14)$ & $(7.49)$ & $(3309)$ & $(3094)$ & $(2663)$ & $(2782)$ \\
\hline \multirow[t]{2}{*}{ Local } & $-4.45^{*}$ & $-4.24^{*}$ & -578 & -1096 & -1007 & $-1194^{*}$ \\
\hline & $(2.09)$ & $(2.42)$ & $(1200)$ & (1084) & $(963)$ & (1010) \\
\hline \multirow[t]{2}{*}{ KavR } & $-10.1^{* *}$ & -7.80 & -824 & -2400 & -1917 & -2533 \\
\hline & $(4.29)$ & (6.33) & (2597) & $(3313)$ & $(2173)$ & (2413) \\
\hline Controls & Yes & Yes & Yes & Yes & Yes & Yes \\
\hline N.of Obs. & 2256 & 1595 & 1848 & 1383 & 1830 & 1365 \\
\hline R-Squared & 0.055 & 0.035 & 0.055 & 0.049 & 0.047 & 0.043 \\
\hline
\end{tabular}

Note: Results for Start-up entrepreneurs only. The controls are: individuals' gender, age, familial status, number of children, job tenure and average hours worked per week; indicators for the size of the city or town where the individual lives; dummies for educational achievement, less than full year jobs, sector of occupation and calendar years; 5 regional block controls. KavR is the index of Local Financial development (Capital Availability) at the Region Level. See body text and Guiso at al. (2004a) for more details. All estimates instrument KavR and its interaction by the structure of the Banking system in the region in 1936, see text. Columns 1,3, and 5 consider KavR in the region of residence while the remaining ones deals with KavR in the region of birth. Robust S.E. in parentheses with p-value $<0.10={ }^{*}, \mathrm{p}$-value $<0.05$ $=* *$, p-value $<0.01=* * *$. 


\section{CEMFI WORKING PAPERS}

0301 Rubén Hernández-Murillo and Gerard Llobet: "Patent licensing revisited: Heterogeneous firms and product differentiation".

0302 Cristina Barceló: "Housing tenure and labour mobility: A comparison across European countries".

0303 Víctor López Pérez: "Wage indexation and inflation persistence".

0304 Jesús M. Carro: "Estimating dynamic panel data discrete choice models with fixed effects".

0305 Josep Pijoan-Mas: "Pricing risk in economies with heterogenous agents and incomplete markets".

0306 Gabriele Fiorentini, Enrique Sentana and Giorgio Calzolari: "On the validity of the Jarque-Bera normality test in conditionally heteroskedastic dynamic regression models".

0307 Samuel Bentolila and Juan F. Jimeno: "Spanish unemployment: The end of the wild ride?".

0308 Rafael Repullo and Javier Suarez: "Loan pricing under Basel capital requirements".

0309 Matt Klaeffling and Victor Lopez Perez: "Inflation targets and the liquidity trap".

0310 Manuel Arellano: "Modelling optimal instrumental variables for dynamic panel data models".

0311 Josep Pijoan-Mas: "Precautionary savings or working longer hours?".

0312 Meritxell Albertí, Ángel León and Gerard Llobet: "Evaluation of a taxi sector reform: A real options approach".

0401 Andres Almazan, Javier Suarez and Sheridan Titman: "Stakeholders, transparency and capital structure".

0402 Antonio Diez de los Rios: "Exchange rate regimes, globalisation and the cost of capital in emerging markets".

0403 Juan J. Dolado and Vanessa Llorens: "Gender wage gaps by education in Spain: Glass floors vs. glass ceilings".

0404 Sascha O. Becker, Samuel Bentolila, Ana Fernandes and Andrea Ichino: "Job insecurity and children's emancipation".

0405 Claudio Michelacci and David Lopez-Salido: "Technology shocks and job flows".

0406 Samuel Bentolila, Claudio Michelacci and Javier Suarez: "Social contacts and occupational choice".

0407 David A. Marshall and Edward Simpson Prescott: "State-contingent bank regulation with unobserved actions and unobserved characteristics".

0408 Ana Fernandes: "Knowledge, technology adoption and financial innovation".

0409 Enrique Sentana, Giorgio Calzolari and Gabriele Fiorentini: "Indirect estimation of conditionally heteroskedastic factor models".

0410 Francisco Peñaranda and Enrique Sentana: "Spanning tests in return and stochastic discount factor mean-variance frontiers: A unifying approach".

0411 F. Javier Mencía and Enrique Sentana: "Estimation and testing of dynamic models with generalised hyperbolic innovations".

0412 Edward Simpson Prescott: "Auditing and bank capital regulation". 
0413 Víctor Aguirregabiria and Pedro Mira: "Sequential estimation of dynamic discrete games".

0414 Kai-Uwe Kühn and Matilde Machado: "Bilateral market power and vertical integration in the Spanish electricity spot market".

0415 Guillermo Caruana, Liran Einav and Daniel Quint: "Multilateral bargaining with concession costs".

0416 David S. Evans and A. Jorge Padilla: "Excessive prices: Using economics to define administrable legal rules".

0417 David S. Evans and A. Jorge Padilla: "Designing antitrust rules for assessing unilateral practices: A neo-Chicago approach".

0418 Rafael Repullo: "Policies for banking crises: A theoretical framework".

0419 Francisco Peñaranda: "Are vector autoregressions an accurate model for dynamic asset allocation?"

0420 Ángel León and Diego Piñeiro: "Valuation of a biotech company: A real options approach".

0421 Javier Alvarez and Manuel Arellano: "Robust likelihood estimation of dynamic panel data models".

0422 Abel Elizalde and Rafael Repullo: "Economic and regulatory capital. What is the difference?".

0501 Claudio Michelacci and Vincenzo Quadrini: "Borrowing from employees: Wage dynamics with financial constraints".

0502 Gerard Llobet and Javier Suarez: "Financing and the protection of innovators".

0503 Juan-José Ganuza and José S. Penalva: "On information and competition in private value auctions".

0504 Rafael Repullo: "Liquidity, risk-taking, and the lender of last resort".

0505 Marta González and Josep Pijoan-Mas: "The flat tax reform: A general equilibrium evaluation for Spain".

0506 Claudio Michelacci and Olmo Silva: "Why so many local entrepreneurs?". 